Discussion Paper No. 14-085

The Impact of Regulation and Competition on the Migration from Old to New Communications Infrastructure: Recent Evidence from EU27 Member States

Wolfgang Briglauer

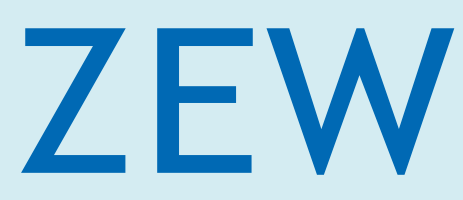

Zentrum für Europäische Wirtschaftsforschung $\mathrm{GmbH}$ Centre for European Economic Research 
Discussion Paper No. 14-085

\section{The Impact of Regulation and Competition on the Migration from Old to New Communications Infrastructure: Recent Evidence from EU27 Member States}

Wolfgang Briglauer

Download this ZEW Discussion Paper from our ftp server:

http://ftp.zew.de/pub/zew-docs/dp/dp14085.pdf

Die Discussion Papers dienen einer möglichst schnellen Verbreitung von neueren Forschungsarbeiten des ZEW. Die Beiträge liegen in alleiniger Verantwortung der Autoren und stellen nicht notwendigerweise die Meinung des ZEW dar.

Discussion Papers are intended to make results of ZEW research promptly available to other economists in order to encourage discussion and suggestions for revisions. The authors are solely responsible for the contents which do not necessarily represent the opinion of the ZEW. 
The Impact of Regulation and Competition on the Migration from Old to New Communications Infrastructure: Recent Evidence from EU27 Member States

Wolfgang Briglauera

October 2014

Keywords: Next-generation communications networks, sector-specific regulation, infrastructure competition, investment conditions, adjustment process, EU27 panel data

JEL: $\mathrm{H}_{5}, \mathrm{~L} 38$, L43, L52

\footnotetext{
a (Corresponding author) Wolfgang Briglauer, Centre for European Economic Research (ZEW Mannheim), e-mail: briglauer@zew.de, phone: +49 (o) 621 1235-279, fax: +49 (o) 621 1235-170. P.0. Box 103443, 68034 Mannheim, Germany.
} 


\section{Executive Summary (ausführliche deutsche Zusammenfassung)}

Betreiber von bisherigen Breitbandnetzen (der ersten Generation) sehen sich mit einem wachsenden Bedarf nach immer breitbandintensiveren Informations- und Kommunikationsdiensten konfrontiert. Der Bedarf geht auf Nachfrageseite etwa einher mit interaktiven Multimedia-Diensten, wie Video on Demand, HD Fernsehen, 3-D Anwendungen, eHealth, eGovernment, cloud computing sowie insbesondere auch mit der massiven Verbreitung von mobilen Breitbanddiensten („mobile apps“), die ebenfalls hohe Anforderungen an die Datenübertragungskapazität in mobilen und festnetzgebundenen Kommunikationsnetzen mit sich bringen. Angebotsseitig werden in Zusammenhang mit dem Ausbau neuer Kommunikationsinfrastrukturen und in Verbindung mit einer zunehmenden Verbreitung von darauf basierenden Internetdiensten hohe Produktivitäts- und Wachstumspotentiale erwartet.

Die Erneuerung bestehender Breitbandinfrastruktur bzw. deren (teilweiser) Ersatz durch Glasfasernetze im Bereich des Teilnehmeranschlussnetzes erfordert jedoch sehr hohe Investitionsvolumina und geht mit hohen Risiken einher. In diesem Zusammenhang stellt sich daher insbesondere auch die Frage nach der optimalen Gestaltung regulatorischer Rahmenbedingungen, die effiziente Investitionen fördern und Investitionsrisiken minimieren sollten. In Hinblick auf die Anreize, neue Kommunikationsinfrastruktur zur Verfügung zu stellen, ist hier zunächst die Auswirkung relevanter sektorspezifischer (ex ante) Regulierungsverpflichtungen auf die dynamische Effizienz zu untersuchen. Konkret wird im Rahmen dieser Untersuchung dabei folgende Forschungsfrage beantwortet: Wie wirken sektorspezifische Zugangsverpflichtungen bzw. ein regulatorisch induzierter Dienstewettbewerb einerseits sowie infrastrukturbasierter Wettbewerb andererseits auf die Investitionsanreize von Anbietern glasfaserbasierter Kommunikationsinfrastrukturen? 
Auf Basis eines aktuellen Paneldatensatzes für (bislang regulierte) Incumbentunternehmen und die Gruppe (bislang unregulierter) alternativer Anbieter in den EU27 Mitgliedsstaaten für die Jahre von 2004 bis 2013 wird zum einen der Einfluss relevanter Vorleistungsregulierungsinstrumente auf die Investitionsanreize in panelökonometrischen Spezifikationen geschätzt. Neben dem Einfluss von Regulierungsvariablen wird zum anderen auch der wettbewerbliche Einfluss von Mobilfunk- und bestehenden festnetzgebundenen Breitbandnetzen bestimmt. Zugleich berücksichtig die empirische Untersuchung explizit relevante nachfrageseitige Determinanten sowie die wesentlichen Determinanten der Netzausbaukosten. Die ökonometrische Spezifikation modelliert dabei auch den dynamischen Verlauf des Investitionsausbaus. Eine große Anzahl an Kontrollvariablen sowie unterschiedliche Modellspezifikationen und Schätzverfahren sollen die Robustheit der erzielten Ergebnisse gewährleisten.

Im Ergebnis zeigt sich zum einen, dass mit einer Intensivierung des regulatorisch induzierten Dienstewettbewerbs um einen Prozentpunkt eine Verringerung der Investitionstätigkeiten im Bereich des Glasfaserausbaus um $1.58 \%$ bis zu $5.30 \%$ einhergeht. Als für den Dienstewettbewerb relevante Vorleistungsregulierungen werden dabei die Entbündelungsverpflichtung, der Bitstromzugang sowie der Wiederverkauf von Breitbandanschlüssen berücksichtigt. Umso effektiver eine hierauf basierende Breitbandvorleistungsregulierung in Form des resultierenden Dienstewettbewerbs umgesetzt wird, umso geringer werden somit die ex ante Anreize für Infrastrukturinvestitionen in neue glasfaserbasierte Kommunikationsnetze ausgeprägt sein. Bezüglich der für Migrations- und ex ante Investitionsanreize relevanten Höhe der Entbündelungsentgelte zeigt sich zudem ein in Hinblick auf die Gesamtinvestitionen positiver Zusammenhang: Umso höher das Entbündelungsentgelt von der Regulierungsbehörde gesetzt wird, umso höher sind damit die 
einhergehenden Investitionsanreize im Durchschnitt. Das diesbezügliche Ausmaß ist dabei auch abhängig von der Effektivität der Entbündelungsverpflichtung, wobei hier gilt, dass je größer der Anteil der entbündelten Leitungen (gemessen an der Anzahl aller Endkundenbreitbandanschlüsse), desto stärker der positive Zusammenhang zwischen der Höhe des Entbündelungsentgelts und den glasfaserspezifischen Investitionstätigkeiten. Der Gesamteffekt wird daher in einem Land wie Deutschland, mit einem überdurchschnittlich hohen Marktanteil an entbündelten Leitungen, entsprechend stark ausfallen. Die empirische Analyse stützt damit die überwiegende Anzahl der bisherigen Ergebnisse theoretischer und empirischer Untersuchungen. ${ }^{2}$

In Hinblick auf den wettbewerblichen Einfluss des Mobilfunkwettbewerbs zeigt sich zum anderen ein tendenziell negativer Zusammenhang, wobei sich dieser nicht in allen Modellrechnungen als statistisch signifikant erwies. Dies ist dennoch ein Hinweis darauf, dass mobile Breitbanddienste bereits ein Substitut zum festnetzgebundenen Breitbandanschluss darstellen und einen derart hohen Wettbewerbsdruck auf festnetzgebundene Breitbanddienste ausüben, dass damit ex ante Investitionsanreize im Festnetzbereich gesenkt werden. Es zeigen sich ferner Hinweise darauf, dass bei bereits flächendeckend vorhandener kupferbasierter Infrastruktur des Incumbent-Unternehmens („legacy“) in der kurzfristigen Betrachtung ein negativer Zusammenhang mit Investitionstätigkeiten in Glasfaser zu beobachten ist. Umgekehrt gehen mit der bestehenden Breitbandinfrastruktur der Kabelnetzbetreiber positive Investitionsanreize für den Glasfaserausbau einher. Diese Unterschiede können mit den jeweils unterschiedlichen zusätzlichen Ausbaukosten der existierenden Netze sowie der Vorleistungsregulierung des Incumbents erklärt werden.

\footnotetext{
${ }^{2}$ Vgl. Briglauer \& Frübing (2014) für einen aktuellen deutschsprachigen Überblick über bisherige theoretische und empirische Studien.
} 
In diesem Zusammenhang konnte auch gezeigt werden, dass mit einer gut etablierten Breitbandinfrastruktur der ersten Generation auch erhebliche kundenseitige Wechselkosten einhergehen. Neben nachfrageseitigen Wechselbarrieren bzw. einer ausgeprägten Substitutionsbeziehung zwischen bestehenden Breitbanddiensten und glasfaserbasierten Breitbanddiensten erweisen sich gegenwärtig vor allem auch die sektorspezifische Regulierungspolitik bzw. die für bestehende und künftige Kommunikationsinfrastrukturen vorgesehenen Vorleistungsverpflichtungen als Hemmnis für umfangreichere Investitionstätigkeiten im Bereich des Ausbaus glasfaserbasierter Zugangsrealisierungen. Zwar unterliegt der Glasfaserausbau in den EU27 Staaten einem, wenn im Durchschnitt auch auf geringem Niveau stattfindenden, dynamischen Anpassungsprozess. Dennoch bleibt es fraglich, inwiefern der gegenwärtige EU-Regulierungsrahmen nicht den von der Europäischen Kommission in ihrer „Digitalen Agenda“ selbst gesetzten Ausbau- und Versorgungszielen entgegensteht. In weitest gehender Übereinstimmung mit der bisherigen empirischen Evidenz zeigen die vorliegenden Untersuchungsergebnisse vielmehr, dass deregulatorische Maßnahmen in Hinblick auf die Breitbandinfrastruktur der ersten und nächsten Generation und die dynamische Effizienz erforderlich wären. 


\begin{abstract}
Fibre-deployment of next-generation communications networks is currently a major challenge for investing firms as well as for national regulators and is also subject to hot debates at EU level. This work examines the role of regulatory policies and competition controlling for relevant supply and demand side factors. Our econometric model employs dynamic panel data methods that take into account potential endogeneity due to omitted heterogeneity, reverse causality and the dynamic investment specification.

Our results indicate that relevant forms of previous broadband access regulations have had a negative impact on investment in new infrastructure. Furthermore, infrastructure-based competition from mobile operators and the replacement effect stemming from the incumbents' existing infrastructure exert a negative impact on ex ante investment incentives. As regards the dynamics of the adjustment process, we find that there are both short-term and long-term effects towards the desired infrastructure level.
\end{abstract}




\section{Introduction and motivation}

During the last decade fibre-deployment of telecommunication access networks ("second" or “Next Generation Access (networks)" - NGA(N)) became a major issue for national regulatory authorities (NRAs) as well as for investing firms. Operators of copper- and coax-based ("first generation") broadband networks have to speed up their networks to fulfil needs for highbandwidth demanding multimedia services such as streamed video on demand, high definition television, 3-D applications, cloud computing, Web 2.0 services. Moreover, providers of wireline first-generation broadband networks are confronted with an increasing capacity demand of mobile operators who are subject to an explosion of mobile broadband services. However, the need for network and capacity upgrades not only comes from the demand-side but proponents of a broad-scale roll-out of NGAN also argue with reference to the generalpurpose technology character (Bresnahan \& Trajtenberg, 1995) of NGANs and related spillover effects: NGANs are expected to induce significant productivity improvements and growth across major economic sectors such as health, electricity and transport. Numerous studies exist that provide evidence on the positive impact of first-generation broadband infrastructure in particular on employment, productivity and economic growth. ${ }^{1}$ In a similar vein, proponents of a broad-scale fibre-deployment argue that NGA infrastructure creates new jobs in information and communications technologies (ICT) and other related industries and involves a huge potential for productivity increases and GDP growth. ${ }^{2}$

\footnotetext{
${ }^{1}$ See inter alia Röller and Waverman (2001), Koutroumpis (2009) and Czernich, Falck, Kretschmer and Wößmann (2011) for the impact on GDP growth, Garbacz and Thompson (2007) for the impact on global productive efficiency and Etro (2009) for the impact on business creation and employment.

2 OECD (2009) argues that even slight spill-over effects are sufficient for justifying subsidies for NGA broad-scale deployment.
} 
However, as deployment of NGANs comes along with high investment requirements and risks, 3 identifying the right policy measures becomes crucial. To the extent that investment in NGANs and a higher related level of adoption of NGA-based services is welfare enhancing, dynamic efficiency becomes an important policy goal. Regarding ex ante NGA investment, the "Averch-Johnson" effect (too much capital employed) can be expected to be small because service-based as well as infrastructure-based competition has already transformed monopolylike market structures into much more competitive ones during the last two decades of liberalization and sector-specific regulation. Also, migration towards NGA infrastructure constitutes typically more symmetric markets with new market players (Briglauer \& Gugler, 2013) and thus even higher levels of competition. Moreover, as argued above, one can expect substantial positive externalities of NGA investment that are not captured in the markets.

With regard to the role of NRAs, the question thus arises whether the emerging NGA infrastructure should be subject to access regulations or whether "softer" regulations such as a temporary removal of ex ante obligations ("regulatory holidays") should be granted and how existing broadband regulations, in particular the level of the relevant wholesale access charges, impact migration incentives to NGANs? In view of the comparatively strict EU access regulations imposed on the old broadband infrastructure and as foreseen for emerging NGA infrastructure (Vogelsang, 2014; Briglauer \& Gugler, 2013; European Commission, 2010a), we would like to examine the following research questions related to the group of EU27 member states which are all subject to the same regulatory framework: i) what is the impact of ex ante

\footnotetext{
3 The renewal of existing networks and their (partial) replacement by fibre-optic infrastructure are of much greater magnitude than the previous investments required for upgrading first generation copper networks to facilitate broadband services and add up to billions of euros for a nationwide NGA deployment (FTTH Council Europe, 2012a).
} 
broadband access regulations in terms of the regulated wholesale access charge and related service-based competition on NGA investment? ii) what is the impact of infrastructure-based competition stemming from the mobile sector and first-generation wireline broadband infrastructures on second-generation (NGA) infrastructure?

Our empirical investigation utilizes a comprehensive and a most recent panel data set for $\mathrm{EU}_{27}$ member states for the years from 2004 to 2013. Our econometric estimation techniques explicitly account for the endogeneity bias arising from the dynamic investment specification and from potential endogeneity due to omitted heterogeneity or reverse causality. Furthermore, we employ a set of different regulatory variables that have only been used separately in the empirical literature so far. In particular, we measure regulation in terms of the unbundling charge which is the most relevant wholesale access charge as regards migration incentives to NGANs as well as by the extent of service-based competition that expresses the effectiveness of all forms of broadband access regulations imposed under the EU framework. The three relevant access obligations include in ascending order of investment requirements and scope for product differentiation: i) pure "reselling" services that only offer some scope of differentiation related to retailing the services; ii) wholesale access based on "bitstreaming" and iii) "unbundling the local loop (ULL)" which offers the highest degree of quality differentiation. In addition, we use a formal regulatory density index as a robustness variable. In a similar vein, we take account of the relevant forms of infrastructure-based competition stemming from i) mobile (wireless) networks (“intermodal”) and ii) wireline first-generation broadband networks ("intramodal”). In line with the previous literature our results indicate a negative impact of broadband access regulations on dynamic efficiency in terms of lower total NGA investment, and that the first-generation infrastructure stock of the incumbent gives rise to a replacement effect, which is not the case for cable entrant operators. Furthermore, we find 
that the size of the previous broadband market exerts a positive impact, whereas a high rate of broadband saturation establishes substantial switching costs as regards migration to NGAbased services. In addition, we show that the basic results related to NGA investment also carry over to the corresponding output related measure of NGA adoption. A multiplicity of methods in conjunction with a broad set of control variables ensures the robustness of our results.

Section 2 first provides a brief overview of the industry background and outlines the relevant NGAN scenarios. Section 3 reviews the recent and NGA-related empirical literature focusing on the relation between NGA investment and broadband access regulations. Section 4 then outlines testable hypotheses concerning the role of sector-specific access regulations and regulatory-induced service-based competition as well as infrastructure-based competition. Section 5 describes our panel data set. Section 6 presents the empirical baseline specification and our identification strategy. Section 7 discusses the empirical results. Finally, section 8 summarizes and compiles relevant policy recommendations.

\section{Industry background: Relevant NGAN scenarios}

As indicated in the introduction, bandwidth of existing first-generation broadband networks is limited. In order to realise NGA characteristic connection speed and enable NGA specific applications, it is necessary to shorten the length of the copper-based local loops by placing the transmission equipment closer to the retail customers' premises, e.g. in the cabinets which house distribution frames (referred to as "fibre to the curb/cabinet" (FTTC)). Even higher bandwidths can be achieved if the final copper-wire line is extended to or into the building (Fibre to the building (FTTB)). In case where technical and economic considerations render it feasible to also renew or replace the remaining in-house wiring and hence to eliminate copper lines entirely, fibre can be directly deployed to the individual apartment or home ("fibre to the 
home" - FTTH) (Briglauer, Gugler \& Ecker 2013:144). In addition to these deployment scenarios, the roll-out of high-speed communications networks might also be realised by upgrading traditional cable television networks based on DOCSIS 3.0 technology (referred to as "fibre-tothe-last-amplifer" (FTTLA)).

In the following we will use the generic term "fibre to the $x$ " (FTTx) to refer to any NGA broadband networks using either FTTH/B/C or FTLA architectures. ${ }^{4}$

\section{Empirical evidence}

Empirical literature related to the impact of broadband access regulations can be divided into two broad categories: i) quantitative analysis focusing on the impact on NGA investment and ii) quantitative analysis focusing on the impact on NGA adoption. We also consider the latter category here, since most of the empirical studies refer to measures of adoption due to data availability and as some authors explicitly argue measures of adoption are output-related and hence might provide a better proxy for welfare in efficiently functioning markets (Crandall, Jeffrey \& Ingraham, 2013:266).

Briglauer et al. (2013) were the first to investigate the determinants of NGA investment in terms of homes passed by FTTx connections using data for the years from 2005 to 2011 . Their empirical specification incorporates EU27 country-level data based on a small number of observations. The authors find that the more effective service-based competition is, the more negative is the impact on NGA deployment. Competitive pressure from cable and mobile networks affects NGA deployment in a non-linear manner.

\footnotetext{
4 Mobile broadband networks based on the wireless communication standard "Long Term Evolution" (LTE) might reach similar coverage and adoption in view of the enormous popularity of mobile apps and also compete in terms of quality of service levels with FTTx architectures in the mid-term.
} 
Wallsten and Hausladen (2009) were the first to estimate the effects of broadband access regulation on FTTx adoption with data from EU27 countries for the years from 2002 to 2007. Hence, this work covers the NGA roll-out at the very early stage. The authors find that countries where unbundled local loops or bitstream unbundling is more effective experience lower fibre adoption. In turn, infrastructure-based competition exerts a positive impact on fibre adoption.

Samanta, Martin, Guild and Pan (2012) examine the demand-side determinants of highspeed broadband deployment using ITU and OECD data on the number of FTTx connections for 25 countries for the years from 1999 to 2009. The authors employ a dummy variable to capture the extent of unbundling regulation and find that this variable has no significant impact on NGA adoption.

Bacache, Bourreau and Gaudin (2014) examine the incentives embedded in the EU regulatory framework on migration from old to new access infrastructures using data from 15 European member states for 17 semesters over the period from July 2002 to July 2010 . The authors relate the number of access lines based on FTTx access to the number of unbundling and bitstream lines in order to test the validity of the so-called "ladder of investment" hypothesis (Cave and Vogelsang 2003; Cave 2006) according to which, regulatory-induced service-based competition serves as a stepping stone for entrants to engage progressively in backward integration. Whereas the authors find some support for the ladder of investment hypothesis for the migration from bitstream access to local loop unbundling at the lower rungs of the ladder, there is no empirical support for the hypothesis that the presence of multilayer access regulation to local loop encourages entrants to invest in NGA infrastructures.

Finally, Briglauer (2014) investigates the determinants of NGA adoption based on FTTX subscriptions for EU27 member states for the years from 2004 to 2013 . The author finds that 
stricter previous broadband regulations in terms of unbundling, bitstream access and resale access obligations have a negative impact, while competitive pressure from first-generation broadband and mobile networks affects NGA adoption in a non-linear manner.

Summarizing, only one study that uses OECD and ITU data for FTTx adoption finds insignificant results. Otherwise, the empirical literature clearly indicates that all studies that employ EU data or data from European countries find a negative impact of ex ante access regulations or related service-based competition on NGA deployment in terms of aggregate FTTx investment or FTTX adoption and hence a negative impact on dynamic efficiency or welfare. This appears to be largely in line with the older broadband related literature as surveyed in Cambini and Jiang (2009:571) who find that "[t]he majority concludes that local loop unbundling based on forward-looking cost methodology discourages both ILECs and CELECs from investing in networks."

The literature review also indicates that there are still very few contributions that utilize NGA-related data with only one study utilizing NGA specific investment data which is, however, based on a rather small sample of observations due to the natural data limitations associated with the NGA deployment process. Our data set accommodates a much larger number of observations and variables which increases the precision of estimates considerably and also provides a means for testing the robustness of the present estimation results. Furthermore, none of the reviewed contributions examines the impact of all the relevant regulatory and competition variables as outlined in the introductory section. However, a presentation of the whole picture based on robust empirical and methodological grounds appears to be essential for the policy debate and still missing. This work intends to fill this gap. 


\section{Hypotheses}

Our testable hypotheses on the main variables of interest are deduced from the theoretical literature and outlined in sections 4.1 and 4.2. Section 4.3 describes relevant NGA investment determinants on the demand and cost sides as well as the dynamics of the NGA investment process.

\subsection{Sector-specific regulation and service-based competition}

The theoretical literature first suggests that less restrictive access regulations imposed on firstand/or second-generation infrastructure, for instance the permission of risk-sharing models and cooperation models, geographically differentiated access charges or temporary regulatory holidays in conjunction with voluntary access would be beneficial to encourage NGA investment, while strict forms of cost-based access regulation would lead to lower incentives for NGA investment (Nitsche \& Wiethaus, 2011; Cambini \& Silvestri, 2012; Bourreau, Cambini \& Dogan, 2014). This gets reinforced in view of demand uncertainty (Klumpp \& Su 2010) and in case that NGANs represent an investment in quality (Vareda, 2010) and a non-drastic innovation (Brito, Pereira \& Vareda, 2010). It appears that these features are indeed characteristic to NGA deployment and hence the stricter access is regulated the lower investment incentives will be. This expectation also relates to the effectiveness of servicebased competition which is directly conducive to the intensity of the "treatment" of the individual regulatory policies (Bacache et al., 2014).

Second, one has to consider expectations that are shaped on the basis of the existing infrastructure regulation although this effect is not explicitly covered in the related theoretical literature so far. In the particular case of NGA deployment, potential investors will ceteris paribus expect stricter future access regulations of NGA infrastructure, the stricter the existing first-generation broadband infrastructure is regulated. However, rents earned from wholesale 
access at cost-oriented prices are lower than rents from selling infrastructure directly to retail customers. Expectation effects thus lower net present values and hence the ex ante incentive to invest for those operators who will most likely be subject to mandatory fibre access regulations. This gets reinforced in case risks are shifted from entrants to incumbents which is typically the case under standard cost-based access regimes. And vice versa, service-based competitors anticipate benefiting from the risk-free option due to expected mandatory access obligations and hence ex ante NGA investment incentives will be lower for entrants as well (Valetti, 2003; Pindyck, 2007). Moreover, infrastructure investors might also expect that they will be subject to a regulatory commitment problem and to regulatory opportunism meaning that the NRA has an incentive to enforce cheap wholesale access once the new infrastructure is established on a large scale irrespective of former decisions and announcements. Regulatoryinduced service-based competition would lead to higher NGA investment incentives only if the ladder of investment hypothesis holds true and induces sufficient migration to self-deployed NGA infrastructure or if service-based broadband competition leads to increases in variety and innovation and, hence, total broadband demand. This demand-increasing effect might also increase ex ante investment incentives for incumbents if they can appropriate profits through sufficiently high access charges (Foros, 2004; Kotakorpi, 2006).

Third, in case that cost-based access regulation is imposed on the first-generation infrastructure by NRAs, the theoretical literature (Inderst \& Peitz, 2012; Bourreau et al., 2012) suggests that a lower access charge for the old technology reduces NGA investment by the entrant as the availability of a cheap access increases opportunity costs of the entrant's investment in new infrastructure. However, the literature finds countervailing effects for the incumbent (Bourreau et al., 2012): on the one hand, the "business migration effect" suggests that a lower access charge would imply that prices charged for NGA services have to be rather 
low as well or customers would not switch, implying negative implications for investment incentives. On the other hand, there is the "wholesale revenue effect", which assumes that high investment by the incumbent triggers high investment by the entrant, resulting in a loss of wholesale revenues, but this loss is smaller with lower access charges. Overall, at the firm level there is some ambiguity concerning the question of whether a higher or lower access charge is more likely to induce NGA investment by the incumbent and hence also with respect to aggregate NGA investment.

Summarizing, from the theoretical literature we expect that service-based competition and related access regulations exert a negative impact on entrants' investment incentives if the ladder of investment hypothesis does not hold true and does not dominate the other effects. With respect to the investment incentives of the incumbent, the overall effect is indeterminate to the extent that service-based competition also captures the effect of the height of regulated access charges and induces total demand increases. Similarly, we expect that entrants' investment incentives are positively related to the height of the access charge, whereas the impact on NGA investment incentives of the incumbent is indeterminate. With regard to aggregate NGA investment the empirical literature clearly suggests that service-based competition as well as related access regulations exert a negative impact. Note that although different investment incentives can be identified at the firm level, most notably between regulated incumbent operators and unregulated service-based or infrastructure-based entrants, aggregate industry investment represents the main point of reference for policymakers.

\subsection{Infrastructure-based competition}

Mobile networks have become the main intermodal competitor for wireline providers both with respect to narrowband as well as broadband services. This phenomenon has been referred to 
as fixed-mobile substitution (FMS), which now exerts a crucial impact on existing and future market structures and thus also on NGA investment incentives. Indeed, some of the empirical studies reviewed in section 3 found a significant and non-linear relationship between the extent of FMS and NGA investment. A standard interpretation of this result follows the reasoning in Aghion, Bloom, Blundell, Griffith and Howitt (2005) according to which operators first try to „escape” competition and capture monopolistic rents by an innovation at moderate levels of competition whereas at high levels of competition operators are not able any longer to generate sufficient future profits for investment/innovation (“Schumpeterian" effect). These opposing effects will then imply an "inverted U-shaped" relationship. However, as shown in Schmutzler and Sacco (2011) there is generally no clear prediction at the micro-level. Rather, the relationship depends on the definition of competitive intensity and the oligopoly framework and consequently investments can be increasing or decreasing functions of competition. Also, an inverted U-shaped relation is not necessarily more likely than a U-shaped relation.

In view of the first-generation (intramodal) broadband infrastructure that is basically based on copper-lines and DSL technology of the incumbents ("legacy”) as well as coaxial cabling infrastructure and the hybrid-fibre technology of cable-TV network operators, we also have to consider the well-known "replacement" effect (Arrow, 1962). Accordingly, NGA investments would cannibalize rents on conventional broadband services which represent an opportunity cost of NGA deployment. In particular, in the case of a well-established firstgeneration broadband infrastructure stock that enables high-quality broadband services and broad consumer acceptance, the replacement effect might be substantial and thus hinder or delay NGA deployment.

Summarizing, there is no clear prediction regarding the impact of intermodal competition from mobile networks on NGA investment incentives. The replacement effect 
implies that incumbent and entrant (cable) operators are reluctant to network upgrades. This effect will be more pronounced the lower the quality and profit differential between the firstgeneration and second-generation broadband infrastructure is.

\subsection{Demand and cost controls and investment dynamics}

Both the level and the speed of NGA deployment will also be influenced by variables related to consumer demand and (adjustment) costs of the NGA infrastructure roll-out.

On the one hand, costs depend on population or household density and other demographic characteristics. Urbanization is perhaps a better measure of deployment costs than household or population density, because a hypothetical move of all households to one city would not change average household density but would have a massive impact on average NGA deployment costs (Vogelsang, 2014:3). Also, the housing structure, in particular the number of multi-dwelling units, determines average deployment costs (FTTH Council Europe, 2012b:24-25). On the other hand, civil engineering and construction costs (including in-house wiring) represent by far the most relevant cost drivers, which will also depend on topographic region or country-specific characteristics. Finally, one has to be aware that NGA roll-out is a rather time-consuming process as it involves complex technical network planning and standardization, and legal issues such as co-ordination with NRAs and potential access seekers, rights of way or other allowances such as contractual obligations with house owners have to be resolved beforehand. As a consequence, operators cannot immediately adjust their infrastructure stock to changing market conditions and it is likely that adjustment to optimal infrastructure stocks will take place only gradually over time. Partial adjustment towards a long-run optimum also captures the feature of increasing marginal costs of NGA deployment which reaps "low-hanging fruits" first and leaves "white areas" uncovered. 
Demand and the willingness to pay for NGAN services depend on the overall size of the broadband market and the degree of innovation and the intensity of consumers' use of broadband services. Whereas traditional broadband services exhibit fairly stable demand, demand for NGA services is much more uncertain and seems to have more luxury characteristics (Muselaers \& Stil, 2010:6) and hence it will also depend on consumer wealth in general. Moreover, the demand for NGA services is also driven by a variety of consumer preferences, referring to the overall affinity with ICT and Internet usage and the usage intensity of high-speed broadband services on the part of residential or business customers. Consumers' needs are furthermore determined by their average education levels, since higher levels of education improve e-literacy skills, which considerably increases the utility derived from NGA technologies. Also, more highly educated people tend to be more prone to adopting and experimenting with new ICT (Kiiski \& Pohjola, 2002:302; Briglauer, 2014). While the demand determinants described above drive NGA investment, consumer demand might also be subject to switching costs. In cases where conventional broadband services enjoy broad consumer acceptance in terms of quality characteristics and high market saturation or the incremental benefits of moving to NGA services are not large and transparent enough for consumers, switching costs might be substantial and hinder consumer migration and thereby reducing NGA investment incentives. The higher market saturation is in terms of per household or per capita adoption of broadband services, the lower is the remaining segment of consumers that can be directly migrated to NGA services without having to overcome switching costs. The latter reduce the profitability of NGA investment, since operators have to convince largely satisfied consumers to switch via offering costly price discounts or the like.

Summarizing, the higher deployment costs are or the more unfavourable countryspecific deployment characteristics are, the lower NGA investment activities will be. With 
respect to the investment dynamics and adjustment costs we expect that the nature of cost factors and institutional rigidities imply a gradual (partial) adjustment process, however, adjustment towards a long-run optimal infrastructure stock takes place. With respect to the demand determinants, we expect that willingness to pay for broadband services, the ICT affinity of consumers and the education level are positively related to NGA investment. Given that we control for demand-side variables related to the overall ICT affinity, broadband market saturation primarily captures switching costs that hinder migration to NGA services and thus lower ex ante NGA investment incentives.

\section{Data}

We use the following data sources: The European Commissions' "Progress Report on the Single European Electronic Communications Market" in conjunction with its "Digital Agenda Scoreboard" provides yearly data on all relevant wholesale broadband access regulations as well as cable and DSL-related data for our wireline competition variables. In addition, we use a regulatory density index of "Polynomics". Our second main source is the database of FTH Council Europe, which includes annual numbers of deployed NGA lines for incumbent operators and the group of entrants for the EU 27 member states. EUROSTAT provides data on population, education, housing structure and wage costs. Furthermore, we use data from "Marketline" on mobile competition and urbanization, data from International Telecommunications Union (ITU) on fixed-legacy infrastructure, and data from "Euromonitor" on Internet usage and ICT affinity. Finally, the World Bank's “World Development Indicators" provide us with GDP per capita. We use a slightly unbalanced panel data set of EU27 countries 
for the time range from 2004 to 2012 for yearly data on our independent variables and from 2005 to 2013 for yearly data on our dependent variable. 5

All sources and variable definitions are listed and described in detail in Table A.1, while summary statistics are provided in Table A.2 in the Appendix. Section 5.1 and section 5.2 below describe our dependent and independent variables, respectively.

\subsection{Dependent variable}

Our dependent variable, fttx_total, measures the total number of NGA connections deployed ("homes passed") based on all relevant FTTx technologies according to the technical definition in section 2. Our dependent variable represents real FTTx investment in physical units ${ }^{6}$ deployed by European incumbent operators and the group of European entrants. Stacking this firm-level information on our dependent variable allows us to estimate an aggregate model on the basis of a sample size that is twice as large, i.e. we have a maximum of $2^{\star}\left(27^{\star} 9\right)$ observations available (less the missings mentioned in footnote 5 ). Note that the term homes passed refers to the number of consumers that have potential access via FTTx, but which do not necessarily have a corresponding retail contract. In turn, "homes connected" represents the number of adopting consumers who also show a sufficient willingness to pay for at least one of the FTTx-based services. We employ the total number of homes connected, fttx_sub, as well as the total number of homes passed per household, fttx_total_w, as robustness variables.

\footnotetext{
5 Data availability varies randomly by country; most notably, the European Commission does not provide market data for Bulgaria and Romania until 2005, which, creates four missing values. Apparently, this cannot be attributed to NGA deployment activities in these countries.

${ }^{6}$ We consider a real measure of investment superior to monetary measures of investment, for both empirical and conceptual reasons as argued in Briglauer et al. (2013:footnote 17).
} 


\subsection{Independent variables}

In line with our hypotheses in sections 4.1 to $4 \cdot 3$, we can divide the explanatory variables into the following three categories: i) regulation and related service-based competition; ii) infrastructure-based competition; and, iii) control variables focusing on demand and cost determinants of NGA investment.

Broadband access regulation is measured first by the effectiveness of service-based competition, $s b c_{-} b b$, which is the share of regulated and actually used wholesale broadband lines (based on unbundling, bitstream and resale obligations) related to the total number of retail broadband lines. The variable $s b c_{-} b b$ incorporates the actual market effectiveness of access broadband regulations by linking these to the corresponding market outcomes (Bacache et al., 2014; Briglauer et al., 2013). Second, we use the unbundling access charge, price_ull, which stands for the access regulation that is most relevant in view of the migration from old to new broadband networks and is directly set by the NRAs. Third, we use a subindex of the "Polynomics Regulation Index", rdi_bb, which provides a formal measure of relevant EU broadband access obligations as a regulatory robustness variable.7

Infrastructure-based competition is measured in two ways: First, intermodal wireless competition from mobile networks is measured by the extent of FMS. The variable fms relates the total number of mobile lines to the total number of fixed lines. Second, the variables cable and legacy measure the first-generation infrastructure stock of cable and incumbent operators,

\footnotetext{
7 In contrast to the variable $s b c_{-} b b$, the variable $r d i_{-} b b$ captures only the formal aspects of regulation and not its effectiveness and related market outcomes. Indeed, certain access regulations imposed by NRAs might exist on paper for years without any real effect on the relevant markets. We also use the variable $r d i \_b b$ as a robustness variable because it is available only up to 2010.
} 
respectively, and thus the replacement effect that is related to the existing first-generation access infrastructure (intramodal wireline competition).

Demand and cost shifters are included as control variables. GDP per capita, $g d p_{-} p c_{-} p p p$, captures income effects. The network readiness index, nri, the number of Internet users per capita, int_user, and the share of businesses using local area networks, bus_use_lan, as well as the share of the population with higher education level, edu, capture the overall affinity with ICT and broadband services. The stock of existing broadband lines (in logs), In(bb_lines), acts as a proxy for the market size and thus, for the overall willingness to pay for broadband services in a country. Broadband lines per household, bb_lines_w, measures market saturation in terms of household adoption of conventional broadband services.

With regard to deployment and adjustment costs the variables wage and labcost_con serve as cost proxies for the NGA construction costs. In addition, we include the share of a country's urban population, urban_sh, and the number of building permits for multipledwelling units, mdwell_perm, which reflect different costs due to varying shares of densely populated areas and housing structures.

Finally, we include period-effects, $\lambda$, as well as country fixed-effects, $\theta$, with the latter controlling for time invariant and unobserved heterogeneity. Most notably, NGA-relevant and country-specific fixed effects might be related to some of the main cost conditions, such as topographic and demographic characteristics, rights of way, regulations on digging, local availability of ducts and dark fibre, the costs of fibre equipment or different levels of (regulated) capital costs. Furthermore, demand and supply will also be influenced by public subsidies, which also show only limited variation as regards our analysis period. 


\section{Econometric specification}

In section 6.1 we first present our empirical baseline specification, which excludes robustness variables and considers a market that is not in equilibrium but explicitly accounts for an endogenous adjustment process. In section 6.2 we describe our estimation and identification strategy.

\subsection{Aggregate estimation model}

Our dependent variable provides us with firm-specific NGA investment, which allows us to aggregate these data by country in order to maximize the sample size. The dynamic reducedform model in which total NGA investment is expressed in logs, ${ }^{8} \ln \left(\right.$ fttx_total $\left.{ }_{i t}\right)$, and summed over all firms $j$, for EU member state $i$ and year $t$ reads as follows:

(1)

$$
\begin{aligned}
& \ln \left(f t t x_{-} \text {total }_{i t j}\right)= \\
& \alpha_{0}^{\text {total }}+\beta_{1} s b c_{-} b b_{i(t-1)}+\beta_{2} \text { price_ull }_{i(t-1)} \beta_{3} f m s_{i(t-1)}+\beta_{4} f m s^{2}{ }_{i(t-1)}+ \\
& \beta_{5} \text { cable }_{i(t-1)}+\beta_{6} \text { cable }_{i(t-1)}^{2}+\beta_{7} \text { legacy }_{i(t-1)}+\beta_{8} b b_{-} \text {lines_- } w_{i(t-1)}+\beta_{9} \ln \left(b b_{-} \text {lines }\right)_{i(t-1)} \\
& +\gamma^{\prime} \mathbf{Z}_{i(t-1)}+\theta_{i}+\lambda_{t}+\alpha_{1} \ln \left(f t t x_{-} \text {total }_{i(t-1) j}\right)+\varepsilon_{i t}
\end{aligned}
$$

The dynamic investment adjustment process is captured by including the lagged dependent variable as a right-hand side regressor. If the dynamic specification is correct, then $\alpha_{1}$ is in the interval $[0 ; 1]$. Equation (1) depends on the main variables of interest, i.e. regulation in terms of the variables $s b c \_b b$ and price_ull, and competition, in terms of the variables fms, cable and legacy. Note that we control for the incumbent's replacement effect by including the variable legacy and the entrants' replacement effect by controlling for the stock of entrants' cable infrastructure, cable. In order to estimate non-linear relationships as regards competition from mobile networks and cable infrastructure, as seen in the literature, we also include the squared terms, $f m s^{2}$ and $c a b l e^{2}$, in our baseline specification. Furthermore, equation (1) incorporates

\footnotetext{
${ }^{8} \mathrm{~A} \log$ transformation helps to stabilize the series of our dependent variable.
} 
market size and market saturation effects related to the total broadband market as captured by the variables $\ln$ (bb_lines) and $b b_{-}$lines_w. Finally, we include a vector of demand and cost controls, $Z$, an additive error term, $\varepsilon_{i t}$, country-specific effects, $\theta_{i}$, and period effects, $\lambda_{t} \cdot{ }^{9}$ Note that equation (1) includes lagged values of all the explanatory variables in order to fully employ our available data set.

\subsection{Estimation and identification strategy}

Using dynamic generalized-method-of-moments (GMM) panel data estimation techniques allows us to take into account endogeneity due to unobserved heterogeneity and due to the presence of the lagged dependent variable as a right-hand side variable (Nickell, 1981) in equation (1). Moreover, the related literature (e.g. Grajek \& Röller, 2011) suggests that there might be reverse causality patterns between investment decisions on the one hand and regulation or competition variables on the other. GMM estimators provide us with internal instruments, which appears to be a superior strategy to using external instruments in view of a sufficient number of time periods $(t=9)$ and as we have to treat several independent variables as (potentially) endogenous. Whereas the difference GMM estimator (Arellano \& Bond, 1991) makes use of suitable lags of all endogenous and exogenous regressors as instruments, the system GMM estimator (Arellano \& Bover, 1995; Blundell \& Bond, 1998) uses additional instruments. We use the former to keep the number of instruments as small as possible and because our models show only a limited degree of persistency. Furthermore, the system GMM estimator requires the imposition of an additional assumption on initial conditions of the

\footnotetext{
9 Including period effects allows us to control also for relevant and common industry developments during the period of our analysis such as upgrades in quality or decreases in prices (Grzybowski, 2005:54).
} 
process generating the dependent variable and thus works only under special circumstances (Roodman, 2009).

We also employ a bias-corrected least squares dummy variable estimator (LSDVC) developed by Bruno $(2005 a, b)$ for dynamic unbalanced panel data and a small number of cross-sectional units $(n=27)$. Since we lag all explanatory variables in the specifications in equation (1), these variables can thus be considered as predetermined which mitigates endogeneity problems, if there is no serial correlation. In fact, pre-determinedness is reasonable for dynamic autoregressive models such as in equation (1) (Wooldridge, 2002:299300). Further endogeneity problems due to time-variant heterogeneity should be limited in view of our considerably large number of control variables. Finally, as argued in the related literature, endogeneity due to reverse causality should be limited in our case as well, since we relate determinants of first-generation broadband markets to emerging NGA infrastructure rollout. ${ }^{10}$ However, the LSDVC estimator requires strictly exogenous regressors, which represents a rather strong assumption, and for this reason we consider difference GMM as our main estimator, which is designed for models where right-hand side variables, including the lagged dependent variable, are not strictly exogenous. ${ }^{11}$ Yet, against the background of the different strengths and weaknesses of GMM and LSDVC estimators, it makes sense to employ both in order to ensure the robustness of our results.

\footnotetext{
${ }^{10}$ See Briglauer et al. (2013) and Briglauer (2014) for more detailed justifications for this reasoning and statistical evidence based on Granger causality tests. Generally, as argued in Grzybowski (2005:55-56), NRAs react to demand and supply shocks but typically with substantial delay in view of the legislative and technical implementation process.

${ }^{11}$ Another advantage of the GMM difference estimator is that non-stationarity in aggregate time series can be typically removed by first differencing the series. This is an important feature, since panel unit root tests assume large $t$ and thus cannot be conducted formally in our case $(t=9)$.
} 


\section{Empirical results}

Table 1 to Table 3 below show the main estimation results based on the model specification in equation (1). All standard errors reported are robust and permit arbitrary forms of heteroscedasticity and autocorrelation in the $\varepsilon$ 's for GMM and are bootstrapped for LSDVC models. ${ }^{12}$

As regards the GMM models we treat all regulatory and competition variables as well as the lagged dependent variable as endogenous, whereas demand and cost controls are treated as exogenous. We utilize the Arellano-Bond one-step estimator which is the more efficient alternative in case of estimation in small samples (Roodman, 2009) even in the presence of heteroscedasticity (Bond, 2002). Since GMM estimators incorporate the assumption that the idiosyncratic errors of the untransformed specification are uncorrelated across units, we include period effects in all GMM estimations reported in Table 1 to Table 3 to prevent the most likely source of cross-correlation, i.e. contemporaneous correlation (Roodman, 2006:36). The key identifying assumption underlying the GMM estimator is that the error terms in the original specification, $\varepsilon$ 's, are serially uncorrelated. For all GMM models reported in Table 1 to Table 3 the Arellano-Bond (AR(1) and $A R(2))$ tests for zero autocorrelation in the first-differenced errors reject at order 1 but not at order 2 at conventional levels. This implies, most importantly, that there is no evidence of serial correlation in the original error. Finally, the Hansen tests do not suggest rejection of the overidentifying restrictions at the conventional levels in all GMM models and the Wald tests ( $X^{2}$ statistics) indicate a high significance of all model regressors in all specifications.

\footnotetext{
${ }_{12}$ Stata 12.1 is used to estimate the regressions.
} 


\subsection{Main results}

Table 1 shows the main regression results for alternative specifications as regards regulatory variables, normalization of the dependent variable (In(fttx_total_w) is used in regr. (6) instead of In(fttx_total) and selection of control variables (regr. labelled "Full" and "Final"). Whereas "Full" indicates the inclusion of all available control variables, insignificant or the least significant demand and cost controls are excluded in "Final" regressions. The basic structure of regression estimates that we discuss below is robust in light of these differences in model specifications.

To begin with, Table 1 shows that the coefficient of the lagged dependent variable is highly significant and substantial in all regressions (including those in Table 2 and Table 3) indicating that the dynamic specification is adequate. As expected, the coefficient is between 0 and 1 and lies in the interval of $[0.2234 ; 0.4142]$, which indicates that there are adjustment costs underlying NGA deployment until the long-run desired infrastructure stock is reached. The coefficients for the long-run relationships can be derived from the dynamic model as $\beta_{k} /\left(1-\alpha_{1}\right)$ and $\gamma_{l} /\left(1-\alpha_{1}\right)$. Therefore, the long-run coefficients of the static representation show substantially higher absolute values.

With regard to the group of regulatory variables, we first infer from Table 1 that the negative impact of service-based competition dominates at the aggregate investment level. The coefficient of the variable $s b c_{-} b b$ is significantly negative in all model specifications (including those in Table 2 and Table 3). Furthermore, the economic impact is substantial, as the estimates indicate that an increase in the intensity of service-based competition by 1 percentage point, decreases total NGA investment by at least $\sim 1.58 \%$ and up to a maximum of $\sim 5.30 \%$. This strongly supports our hypothesis outlined in section 4.1 , according to which more effective regulatory-induced access obligations reduce aggregate NGA investment incentives in 
view of the weak empirical evidence for the ladder of investment hypothesis and as regr. (1) to (6) also explicitly control for the demand-expanding effect via the market size variable In(bb_lines). In regr. (2) we utilize our regulatory robustness variable $r d i \_b b$ and drop $s b c_{-} b b$. It appears that the formal regulation index picks up well the effect of service-based competition, suggesting also that the latter captures access regulations adequately. The access charge in terms of the unbundling variable, price_ull, however, is insignificant in all specifications (including those in Table 2 and Table 3). This might be due to the opposing investment incentives as identified in the theoretical literature (Bourreau et al., 2012) but is likely also due to the low degree of variation in the variable price_ull. In particular, as Bacache et al. (2014:205-206) point out, only a very few unbundling access charge increases have been imposed by NRAs in the past, which makes identification of the overall effect difficult. In order to circumvent this problem, we introduce additional variation by referring to a measure that captures the effectiveness of the unbundling regime. Accordingly, the interaction term iprice_ull_shcombines the unbundling charge, price_ull, with the respective unbundling market share, ms_ull. The latter is bound between $\mathrm{o}$ and 1 where the upper limit indicates that all retail broadband connections are offered via unbundling. ${ }^{13}$ From regr. (4) and (5) we infer that the coefficient estimate of the main term price_ull is still insignificant, but the interaction term now shows a significantly positive impact, which increases with a more effective unbundling regime, i.e. with a higher unbundling market share. Evaluated at the grand mean, ms_ull(average) $=0.0997$ (Table A.1), this implies that an increase in the unbundling price by one unit $(1 €)$ increases NGA investment in the range between $2.9 \%$ (regr. (4)) and $6.4 \%$ (regr. (5)). For a

\footnotetext{
${ }_{13}$ This variable might be indeed a better representation of the overall complexity of existing real world unbundling regimes which include many other institutional and technical regulations besides the monthly access charge.
} 
country like Germany, where unbundling is of high market relevance, the impact on NGA investment appears to be even more substantial. For instance, referring to the last observation period as regards our independent variables, i.e. the year 2012, the average unbundling market share in EU27 member states was $15.4 \%\left(m s_{-} u l_{(2012) E U_{27}}=0.154\right)$, whereas the corresponding value for Germany was $\sim 35.2 \%\left(m s_{-} u l_{(2012) \text { Germany }}=0.352\right)$.

With regard to infrastructure-based competition from cable (cable) and mobile ( $f m s)$ operators, we only find weak evidence of a non-linear relationship as found in the previous literature (Briglauer et al., 2013; Briglauer, 2014). Rather, it appears that intermodal competition exerts a negative net impact for all values of the variable $f m s$, whereas intramodal cable competition exerts a positive net impact on NGA investment for all values of the variable cable. The latter finding contrasts with the impact of the first-generation broadband infrastructure stock of the incumbent operator, legacy, which shows a significantly negative coefficient estimate. The different effects might be due to substantial cost differences in upgrading DSL to FTTC and coax-cable to DOCSIS 3.0 technology, respectively. Whereas both first-generation technologies are subject to a replacement effect (opportunity costs), FTTC comes along with comparatively higher deployment costs. In turn, the coax-cable infrastructure experiences low upgrading and hence lower total costs which opens up the potential of migrating the existing subscriber base to NGA/DOCSIS 3.0 services with higher average revenues implying a more favourable profit differential. Furthermore, the variable legacy presumably also captures the effect of the incumbent's opportunity costs related to the wholesale business (referred to as the "wholesale revenue effect" in Bourreau et al., 2012). This interpretation is also consistent with our empirical finding of a positive net impact of the unbundling price on NGA investment in regr. (4) and (5). In turn, the wholesale revenue effect does not exist on the side of the unregulated cable operators. 
With regard to the impact of our control variables, we start by discussing the impact of the demand variables. Most notably, there are strongly countervailing and significant effects related to the variables $b b_{\text {_lines_l}} w$ and $\ln \left(b b_{-}\right.$lines). As outlined in section $4 \cdot 3$, the former is supposed to capture switching costs, since other demand variables already control for ICT affinity of business and residential customers (bus_lan; int_user; nri; edu) and hence the negative coefficient of $b b_{-}$lines_ $w$ is expected. Likewise, the positive coefficient estimate of the variable $\ln \left(b b_{-}\right.$lines) is expected, as it captures the overall broadband market size and thus willingness to pay for broadband services in general. Please note that the variables $b b \_l i n e s \_w$ and $\ln \left(b b_{-}\right.$lines) are correlated with the variables legacy and cable to some extent; ${ }^{14}$ however, dropping the latter does not change the impact of the former as shown in regr. (5).

With respect to our cost controls, the variables wage and urban_sh show expected signs and significant coefficient estimates and apparently capture best deployment costs and topographic deployment conditions, respectively.

14 The reader is referred to the respective definitions in Table A.1 in the Appendix. 
Table 1: Main GMM estimation results

(Dep.var.: In (fttx_total) in regr. (1) to (5); In (fttx_total_w) in regr. (6))

\begin{tabular}{|c|c|c|c|c|c|c|}
\hline Regression nr. & $\begin{array}{c}\text { (1) } \\
\text { Full_total }\end{array}$ & $\begin{array}{c}\text { (2) } \\
\text { Full_total } \\
\text { _ } r\end{array}$ & $\begin{array}{l}\text { (3) } \\
\text { Final_- } \\
\text { total }\end{array}$ & $\begin{array}{c}\text { (4) } \\
\text { Full_i } \\
\text { _ull_price }\end{array}$ & $\begin{array}{c}\text { (5) } \\
\text { Final_i_ } \\
\text { ull_price }\end{array}$ & $\begin{array}{c}\text { (6) } \\
\text { Final__ } \\
\text { total_w }\end{array}$ \\
\hline Dep. var.(t-1) & $\begin{array}{c}0.3751^{\star \star \star} \\
(8.27)\end{array}$ & $\begin{array}{c}0.4025^{\star \star \star} \\
(9.52)\end{array}$ & $\begin{array}{c}0.4142^{\star \star \star} \\
(9.80)\end{array}$ & $\begin{array}{c}0.3801^{\star \star \star} \\
(8.20)\end{array}$ & $\begin{array}{c}0.2234^{\star \star \star} \\
(4.37)\end{array}$ & $\begin{array}{c}0.3299^{\star \star \star} \\
(8.14)\end{array}$ \\
\hline$s b c_{-} b b$ & $\begin{array}{c}-1.5719^{\star \star} \\
(-2.03)\end{array}$ & & $\begin{array}{c}-1.5665^{*} \\
(-1.94)\end{array}$ & $\begin{array}{c}-3.5791^{\star \star \star *} \\
(-3.84)\end{array}$ & $\begin{array}{c}-5.3002^{\star * \star} \\
(-3.92)\end{array}$ & $\begin{array}{c}-3.0296^{\star \star} \\
(-2.56)\end{array}$ \\
\hline price_ull & $\begin{array}{c}0.0054 \\
(0.09)\end{array}$ & $\begin{array}{l}0.0014 \\
(0.02)\end{array}$ & $\begin{array}{c}-0.0489 \\
(-0.87)\end{array}$ & $\begin{array}{c}-0.0235 \\
(-0.35)\end{array}$ & $\begin{array}{c}-0.0910 \\
(-1.16)\end{array}$ & $\begin{array}{c}-0.0056 \\
(-0.08)\end{array}$ \\
\hline i_price_ull_sh & & & & $\begin{array}{c}0.2962^{\star \star} \\
(1.96)\end{array}$ & $\begin{array}{c}0.6463^{\star \star} \\
(2.40)\end{array}$ & \\
\hline rdi_bb & & $\begin{array}{c}-1.9096^{\star \star \star} \\
(-2.86)\end{array}$ & & & & \\
\hline fms & $\begin{array}{c}-1.3152^{\star} \\
(-1.71)\end{array}$ & $\begin{array}{c}-1.1435 \\
(-1.57)\end{array}$ & $\begin{array}{c}-1.4573^{\star} \\
(-1.93)\end{array}$ & $\begin{array}{c}-0.8434 \\
(-1.09)\end{array}$ & $\begin{array}{c}-1.2543 \\
(-1.22)\end{array}$ & $\begin{array}{c}-1.3004 \\
(-1.18)\end{array}$ \\
\hline$f m s^{2}$ & $\begin{array}{c}0.0666 \\
(1.36)\end{array}$ & $\begin{array}{c}0.0632 \\
(1.35)\end{array}$ & $\begin{array}{c}0.0794 \\
(1.57)\end{array}$ & $\begin{array}{c}0.0380 \\
(0.75)\end{array}$ & $\begin{array}{c}0.0844 \\
(1.29)\end{array}$ & $\begin{array}{c}0.0871 \\
(1.28)\end{array}$ \\
\hline cable & $\begin{array}{l}-6.4695 \\
(-1.40)\end{array}$ & $\begin{array}{c}-7.2950^{*} \\
(-1.67)\end{array}$ & $\begin{array}{c}2.7985^{\star} \\
(1.72)\end{array}$ & $\begin{array}{l}-5.9891 \\
(-1.47)\end{array}$ & & $\begin{array}{l}1.3004 \\
(0.60)\end{array}$ \\
\hline cable 2 & $\begin{array}{c}8.5428^{\star \star \star} \\
(3.15)\end{array}$ & $\begin{array}{c}8.3089^{\star \star \star} \\
(3.16)\end{array}$ & & $\begin{array}{c}7.5080^{\star \star \star} \\
(3.11)\end{array}$ & & \\
\hline legacy & $\begin{array}{c}-0.1399^{\star \star} \\
(-2.26)\end{array}$ & $\begin{array}{c}-0.1013^{\star} \\
(-1.89)\end{array}$ & $\begin{array}{c}-0.1491^{\star \star \star} \\
(-3.08)\end{array}$ & $\begin{array}{c}-0.1291^{\star \star} \\
(-2.21)\end{array}$ & & $\begin{array}{c}-0.1590^{\star \star} \\
(-2.12)\end{array}$ \\
\hline$b b \_l i n e s \_w$ & $\begin{array}{c}-21.09^{\star \star \star} \\
(-3.89)\end{array}$ & $\begin{array}{c}-18.116^{\star \star \star} \\
(-4.27)\end{array}$ & $\begin{array}{c}-19.553^{\star \star \star} \\
(-3.46)\end{array}$ & $\begin{array}{c}-23.4043^{\star \star \star} \\
(-3.81)\end{array}$ & $\begin{array}{l}-29.380^{\star \star \star} \\
(-3.91)\end{array}$ & $\begin{array}{c}-17.5572^{\star \star \star} \\
(-3.34)\end{array}$ \\
\hline In(bb_lines) & $\begin{array}{c}1.2984^{\star \star \star} \\
(5.60)\end{array}$ & $\begin{array}{c}1.2870^{\star \star \star} \\
(5.78)\end{array}$ & $\begin{array}{c}0.8152^{\star \star} \\
(2.40)\end{array}$ & $\begin{array}{c}1.1001^{\star \star \star} \\
(5.05)\end{array}$ & $\begin{array}{c}0.8943^{*} \\
(1.77)\end{array}$ & $\begin{array}{c}0.7881^{\star} \\
(1.95)\end{array}$ \\
\hline bus_lan & $\begin{array}{c}-1.3639 \\
(-0.50)\end{array}$ & $\begin{array}{c}-1.4796 \\
(-0.65)\end{array}$ & & $\begin{array}{c}-0.9362 \\
(-0.35)\end{array}$ & $\begin{array}{c}-1.5589 \\
(-0.52)\end{array}$ & \\
\hline$g d p_{-} p c_{-} p p p$ & $\begin{array}{c}0.0002^{\star} \\
(1.75)\end{array}$ & $\begin{array}{c}0.0002 \\
(1.62)\end{array}$ & $\begin{array}{l}0.0001 \\
(1.20)\end{array}$ & $\begin{array}{c}0.0002^{\star \star} \\
(2.12)\end{array}$ & $\begin{array}{c}0.0002^{\star} \\
(1.66)\end{array}$ & $\begin{array}{c}0.0002 \\
(1.42)\end{array}$ \\
\hline
\end{tabular}


Table 1 continued

\begin{tabular}{|c|c|c|c|c|c|c|}
\hline int_user & $\begin{array}{c}2.9754 \\
(1.52)\end{array}$ & $\begin{array}{c}3.4243 \\
(1.33)\end{array}$ & $\begin{array}{c}3.4736 \\
(1.41)\end{array}$ & $\begin{array}{c}4.3653^{\star} \\
(1.93)\end{array}$ & $\begin{array}{c}5.6578^{\star \star} \\
(2.15)\end{array}$ & $\begin{array}{c}1.3126 \\
(0.71)\end{array}$ \\
\hline$n r i$ & $\begin{array}{c}-0.1974 \\
(-0.28)\end{array}$ & $\begin{array}{l}0.1317 \\
(0.18)\end{array}$ & & $\begin{array}{c}0.3843 \\
(0.49)\end{array}$ & & $\begin{array}{c}1.0114 \\
(1.10)\end{array}$ \\
\hline$e d u$ & $\begin{array}{c}-0.0197 \\
(-0.29)\end{array}$ & $\begin{array}{l}0.0131 \\
(0.19)\end{array}$ & & $\begin{array}{c}-0.0175 \\
(-0.26)\end{array}$ & & $\begin{array}{c}0.0129 \\
(0.15)\end{array}$ \\
\hline labcost_con & $\begin{array}{c}0.0244 \\
(1.27)\end{array}$ & & & & & $\begin{array}{c}0.0284 \\
(1.33)\end{array}$ \\
\hline mdwell_perm & $\begin{array}{l}-0.0011 \\
(-1.08)\end{array}$ & $\begin{array}{c}-0.0009 \\
(-1.00)\end{array}$ & & $\begin{array}{c}-0.0015 \\
(-1.64)\end{array}$ & & $\begin{array}{c}-0.0006 \\
(-0.42)\end{array}$ \\
\hline wage & $\begin{array}{c}-0.4358^{\star \star} \\
(-2.48)\end{array}$ & $\begin{array}{c}-0.5459^{\star \star} \\
(-2.92)\end{array}$ & $\begin{array}{c}-0.3190^{\star \star} \\
(-2.03)\end{array}$ & $\begin{array}{c}-0.4219^{\star \star \star} \\
(-2.74)\end{array}$ & $\begin{array}{c}-0.6248^{\star \star} \\
(-2.50)\end{array}$ & $\begin{array}{c}-0.657^{\star \star \star} \\
(-2.64)\end{array}$ \\
\hline urban_sh & $\begin{array}{c}0.8373^{\star \star \star} \\
(4.04)\end{array}$ & $\begin{array}{c}0.4943^{\star \star} \\
(2.18)\end{array}$ & $\begin{array}{c}0.6519^{\star \star \star} \\
(3.80)\end{array}$ & $\begin{array}{c}0.7507^{\star \star \star} \\
(4.06)\end{array}$ & $\begin{array}{c}0.7959^{\star \star \star} \\
(3.33)\end{array}$ & $\begin{array}{c}0.6747^{\star \star \star} \\
(2.83)\end{array}$ \\
\hline Yeardummies & YES & YES & YES & YES & YES & YES \\
\hline Constant & $\begin{array}{c}-58.9559^{\star \star \star} \\
(-3.55)\end{array}$ & $\begin{array}{c}-33.3090^{\star} \\
(-1.71)\end{array}$ & $\begin{array}{c}-39.0156^{\star \star \star} \\
(-2.78)\end{array}$ & $\begin{array}{c}-52.7229^{\star \star \star} \\
(-3 \cdot 30)\end{array}$ & $\begin{array}{c}-58.2865^{\star \star \star} \\
(-2.94)\end{array}$ & $\begin{array}{c}-47.2432^{\star} \\
(-1.90)\end{array}$ \\
\hline$x^{2}$ & $2.6376 e+10$ & $7.09 e+09$ & 8495.8089 & $3.8849 \mathrm{e}+09$ & 1896.1466 & 813389.19 \\
\hline$A R(1)$ test & -3.8475 & -3.8177 & -3.8319 & -3.6708 & -3.6144 & -3.3066 \\
\hline $\begin{array}{l}A R(2) \text { test } \\
\text { Hansen test } \\
\text { ( } p \text {-value) }\end{array}$ & $\begin{array}{l}-0.9840 \\
(1.000)\end{array}$ & $\begin{array}{l}0.0485 \\
(1.000)\end{array}$ & $\begin{array}{l}-1.1719 \\
(1.000)\end{array}$ & $\begin{array}{c}-0.7824 \\
(1.000)\end{array}$ & $\begin{array}{l}-1.2130 \\
(1.000)\end{array}$ & $\begin{array}{l}-1.2540 \\
(1.000)\end{array}$ \\
\hline Observations & 428 & 428 & 428 & 428 & 428 & 428 \\
\hline
\end{tabular}

$t$-statistics reported in parentheses are robust to heteroscedasticity in GMM estimates. All GMM estimates are based on the one-step procedure and all endogenous variables in first differences are instrumented with their own lagged levels dated $t-2$ to $t-6$. All regressions include period effects and country-specific fixed effects which are not reported for brevity. For the Arellano-Bond tests for autocorrelation (AR(1) and $\operatorname{AR}(2))$ and the Hansen test of overidentifying restrictions, test statistics and $p$ values, respectively, are reported.

${ }^{*} p<0.10,{ }^{* *} p<0.05,{ }^{* * *}<0.01$. 


\subsection{Further robustness specifications}

In this section we present additional estimations to examine the robustness of the main estimation results depicted in Table 1 . Our robustness tests refer to i) the number of instruments, ii) the measurement of the variables reflecting the unbundling charge, price_ull and i_price_ull_sh, iii) an alternative estimation technique (LSDVC instead of GMM) and iv) an alternative specification of the dependent variable $\left(\ln \left(f t t x \_s u b\right)\right.$ instead of $\left.\ln \left(f t t x \_t o t a l\right)\right)$.

The Hansen tests reported in Table 1 yield a perfect $p$-value of 1 which indicates that instrument proliferation might reduce the ability of the test to detect weak instruments. The number of instruments increases quadratically in $t$, hence we might be confronted with too many instruments and overfitting biases. Although the resulting number of instruments remains manageable with a maximum number of $t-6$ lags, we further restrict the number of lags used as a means of examining the sensitivity of the results to the choice of the lag specification. In Table 2 GMM style instruments are constructed for a maximum number of $t-2$ lags in regr. (1) to (3). In addition, we use STATA's "collapse" option ("_coll”) to further reduce the number of moment conditions in regr. (4) to (5)..$^{15}$ The Hansen test at the bottom of Table 2 shows that gradually reducing the number of instruments produces more reasonable $p$-values ranging from 0.9958 to 0.1119 . Yet, the basic structure of regression results remains the same in Table 2.

First, the range of estimates of the lagged dependent variable is similar to those obtained in Table 1 and overall we get estimates for GMM-based regressions that lie in the interval [0.2158; 0.4209]. Second, the results for the regulatory variables exhibit a similar structure. The coefficient of the variable $s b c \_b b$ shows some additional variation suggesting

\footnotetext{
${ }_{15}$ The "collapse" option creates only one instrument for each variable and lag distance, rather than one instrument for each time period, variable and lag distance.
} 
that the negative impact of service-based competition on NGA investment might be even higher compared to the estimates obtained in Table 1. With regard to the unbundling price variables, regr. (1) and (3) produce results that match well with the interval of estimates identified in Table 1 [0.2962; 0.6463] and in regr. (2) in Table 3 [0.3112]. Thirdly, the regression results in Table 2 confirm the impact of the main demand and cost control variables. In particular, the estimates provide strong evidence for the opposing and substantial effects captured by the variables $b b \_l i n e s \_w$ and $\ln \left(b b \_l i n e s\right)$ and, again, urbanization, urban_sh, appears to be the main driver on the side of cost controls.

Table 3 reports the results for the LSDVC (regr. (1) to (3)) and for GMM estimations where NGA adoption (In(fttx_sub) appears as the dependent variable (regr. (4) to (5)). Using a measure of NGA adoption shows that the basic structure of coefficient estimates as presented in Table 1 (and Table 2) remains the same and hence it also carries over to an output related performance measure. ${ }^{16}$ Interestingly, the negative impact of access regulation on NGA investment also transfers to NGA adoption. This suggests that the negative impact on investment dominates the positive impact of regulation on adoption via lowering the level of retail prices (Briglauer, 2014). Also in line with the previous literature is the finding that some of the demand side variables, such as $g d p_{-} p c_{-} p p p$, int_userand $e d u$ appear to be of particular importance for the adoption of NGA services. Finally, the findings with respect to the lagged dependent variable and different specifications of the regulatory and competition variables appear to be robust also when using the LSDVC estimator.

\footnotetext{
${ }_{16}$ In regressions (4) and (5) we also include the twice-lagged dependent variable because the AR(2) tests indicated model misspecification in the original estimation. As the coefficient of the twice-lagged dependent variable is insignificant, the condition for dynamic stability is fulfilled.
} 
Table 2: GMM robustness results (unbundling charge and lags) (Dep.var.: In (fttx_total))

\begin{tabular}{|c|c|c|c|c|c|}
\hline Regression nr. & $\begin{array}{c}(1) \\
\text { Full_GMM } \\
\text { i_zlags }\end{array}$ & $\begin{array}{c}\text { (2) } \\
\text { Final_GMM } \\
\text { _2lags }\end{array}$ & $\begin{array}{c}\text { (3) } \\
\text { Final_GMM } \\
\text { i__lags }\end{array}$ & $\begin{array}{c}\text { (4) } \\
\text { Full_GMM } \\
\text { _coll }\end{array}$ & $\begin{array}{c}\text { (5) } \\
\text { Final_GMM } \\
\text { _coll }\end{array}$ \\
\hline $\ln ($ fttx_total) & $\begin{array}{c}0.3085^{\star \star \star} \\
(7.15)\end{array}$ & $\begin{array}{c}0.2158^{\star * *} \\
(3.63)\end{array}$ & $\begin{array}{c}0.2201^{\star \star \star} \\
(3.52)\end{array}$ & $\begin{array}{c}0.3287^{\star \star} \\
(2.06)\end{array}$ & $\begin{array}{c}0.4209^{\star \star} \\
(2.48)\end{array}$ \\
\hline$s b c_{-} b b$ & $\begin{array}{c}-3.7883^{* * *} \\
(-3.14)\end{array}$ & $\begin{array}{c}-3.9709^{\star \star \star} \\
(-3.42)\end{array}$ & $\begin{array}{c}-5.0468^{\star \star \star} \\
(-4.99)\end{array}$ & $\begin{array}{c}-11.9978^{\star \star} \\
(-2.16)\end{array}$ & $\begin{array}{c}-10.6200^{\star \star} \\
(-2.11)\end{array}$ \\
\hline price_ull & $\begin{array}{c}-0.0854 \\
(-1.07)\end{array}$ & $\begin{array}{c}-0.1095 \\
(-1.27)\end{array}$ & $\begin{array}{c}-0.1699 \\
(-1.16)\end{array}$ & $\begin{array}{c}-0.0877 \\
(-0.59)\end{array}$ & $\begin{array}{c}-0.1417 \\
(-1.16)\end{array}$ \\
\hline i_price_ull_sh & $\begin{array}{c}0.4217^{\star} \\
(1.88)\end{array}$ & & $\begin{array}{c}0.5025^{\star \star} \\
(2.01)\end{array}$ & & \\
\hline fms & $\begin{array}{l}0.1104 \\
(0.07)\end{array}$ & $\begin{array}{c}1.5833^{*} \\
(1.77)\end{array}$ & $\begin{array}{c}1.0266 \\
(1.33)\end{array}$ & $\begin{array}{c}2.4334 \\
(0.70)\end{array}$ & $\begin{array}{c}-2.0190 \\
(-0.95)\end{array}$ \\
\hline$f m s^{2}$ & $\begin{array}{l}-0.0375 \\
(-0.40)\end{array}$ & $\begin{array}{c}-0.0929 \\
(-1.64)\end{array}$ & $\begin{array}{c}-0.0494 \\
(-0.97)\end{array}$ & $\begin{array}{l}-0.1148 \\
(-0.72)\end{array}$ & $\begin{array}{c}0.1420 \\
(1.17)\end{array}$ \\
\hline cable & $\begin{array}{c}-4.9966 \\
(-0.87)\end{array}$ & & & $\begin{array}{c}23.4004^{\star \star} \\
(2.45)\end{array}$ & \\
\hline cable $e^{2}$ & $\begin{array}{c}7.4831 \\
(1.58)\end{array}$ & & & $\begin{array}{c}-2.3203 \\
(-0.24)\end{array}$ & \\
\hline legacy & $\begin{array}{c}-0.1634 \\
(-1.61)\end{array}$ & & & $\begin{array}{c}-0.0369 \\
(-0.09)\end{array}$ & \\
\hline$b b \_l i n e s \_w$ & $\begin{array}{c}-30.9117^{\star \star \star} \\
(-4.22)\end{array}$ & $\begin{array}{c}-17.1326^{\star \star \star} \\
(-2.64)\end{array}$ & $\begin{array}{c}-14.9857^{\star \star} \\
(-2.06)\end{array}$ & $\begin{array}{c}-52.5388^{\star \star \star} \\
(-2.65)\end{array}$ & $\begin{array}{c}-38.2255^{\star \star} \\
(-2.15)\end{array}$ \\
\hline $\ln (b b$ blines) & $\begin{array}{c}1.0327^{\star \star} \\
(2.25)\end{array}$ & $\begin{array}{c}1.1608^{\star * *} \\
(2.62)\end{array}$ & $\begin{array}{c}0.9760^{\star} \\
(1.74)\end{array}$ & $\begin{array}{c}2.8354^{\star} \\
(1.78)\end{array}$ & $\begin{array}{c}1.8661 \\
(1.64)\end{array}$ \\
\hline bus_lan & $\begin{array}{l}1.6041 \\
(0.49)\end{array}$ & $\begin{array}{c}-0.4770 \\
(-0.14)\end{array}$ & & $\begin{array}{l}1.8995 \\
(0.32)\end{array}$ & \\
\hline$g d p_{-} p c_{-} p p p$ & $\begin{array}{c}0.0003^{* \star} \\
(2.48)\end{array}$ & $\begin{array}{c}0.0002^{\star \star} \\
(2.54)\end{array}$ & $\begin{array}{c}0.0002^{\star \star \star} \\
(2.97)\end{array}$ & $\begin{array}{c}0.0001 \\
(0.65)\end{array}$ & $\begin{array}{c}0.0001 \\
(1.59)\end{array}$ \\
\hline int_user & $\begin{array}{c}4.5203^{\star} \\
(1.74)\end{array}$ & $\begin{array}{c}6.2537^{\star \star} \\
(2.48)\end{array}$ & $\begin{array}{c}5.5064^{\star \star} \\
(2.41)\end{array}$ & $\begin{array}{c}6.4183 \\
(1.42)\end{array}$ & $\begin{array}{c}9.2581^{\star} \\
(1.90)\end{array}$ \\
\hline$n r i$ & $\begin{array}{c}1.8659^{\star \star} \\
(2.24)\end{array}$ & & & $\begin{array}{c}1.8450^{*} \\
(1.83)\end{array}$ & \\
\hline$e d u$ & $\begin{array}{l}0.0301 \\
(0.40) \\
\end{array}$ & & & $\begin{array}{c}-0.2205 \\
(-1.47) \\
\end{array}$ & \\
\hline
\end{tabular}


Table 2 continued

\begin{tabular}{|c|c|c|c|c|c|}
\hline mdwell_perm & $\begin{array}{c}-0.0001 \\
(-0.11)\end{array}$ & & & $\begin{array}{c}-0.0015 \\
(-0.83)\end{array}$ & \\
\hline labcost_con & & & & $\begin{array}{c}0.0553 \\
(1.16)\end{array}$ & \\
\hline wage & $\begin{array}{c}-0.8013^{\star \star \star} \\
(-2.72)\end{array}$ & $\begin{array}{c}-0.3275 \\
(-1.58)\end{array}$ & $\begin{array}{c}-0.3977^{*} \\
(-1.75)\end{array}$ & $\begin{array}{c}-0.3960 \\
(-0.91)\end{array}$ & $\begin{array}{c}1.0735 \\
(1.47)\end{array}$ \\
\hline urban_sh & $\begin{array}{c}1.0256^{\star \star \star} \\
(4.33)\end{array}$ & $\begin{array}{c}0.9225^{\star \star \star} \\
(2.81)\end{array}$ & $\begin{array}{c}0.6509^{\star} \\
(1.94)\end{array}$ & $\begin{array}{c}2.2027^{\star \star \star} \\
(2.60)\end{array}$ & $\begin{array}{c}0.8023 \\
(1.61)\end{array}$ \\
\hline Yeardummies & YES & YES & YES & YES & YES \\
\hline Constant & $\begin{array}{c}-81.5887^{\star \star \star} \\
(-3.51)\end{array}$ & & & & \\
\hline$x^{2}$ & 626588.5189 & 422.8632 & 520.4694 & 782.3861 & 782.7940 \\
\hline$A R(1)$ test & -3.6976 & -2.2246 & -2.4848 & -2.1904 & -2.4246 \\
\hline$A R(2)$ test & -1.1088 & -1.4649 & -1.5859 & 0.0826 & -0.9590 \\
\hline $\begin{array}{l}\text { Hansen test } \\
\text { (p-value) }\end{array}$ & $(1.000)$ & 0.9958 & 0.9983 & 0.4850 & 0.1119 \\
\hline Observations & 428 & 428 & 428 & 428 & 428 \\
\hline
\end{tabular}

$t$-statistics reported in parentheses are robust to heteroscedasticity in GMM estimates. All GMM estimates are based on the one-step procedure. In regr. (1) to (3) endogenous variables in first differences are instrumented with a maximum number of 2 lags of their own levels, i.e. the lagged levels dated $t-2$ are used as instruments. In regr. (4) to (5) we used STATA's "collapse" option provided in the command "xtabond2". When using xtabond2 (instead of STATA's original "xtabond" command), however, STATA does not include a constant term in GMM-diff estimations. Comparison of regr. (1) to (3) shows that exclusion of the constant term only has a moderate impact. All regressions include countryspecific fixed effects as well as period effects which are not reported for brevity. For the Arellano-Bond tests for autocorrelation $(A R(1)$ and $A R(2))$ and the Hansen test of overidentifying restrictions, corresponding test statistics and $p$-values, respectively, are reported.

${ }^{\star} p<0.10,{ }^{* *} p<0.05,{ }^{* *} p<0.01$. 
Table 3: Robustness results (LSDVC and GMM subscriptions)

(Dep.var.: In (fttx_total) in regressions (1) to (3); In (fttx_sub) in regressions (4) to (5))

\begin{tabular}{|c|c|c|c|c|c|}
\hline Regression nr. & $\begin{array}{c}\text { (1) } \\
\text { Full_ } \\
\text { LSDVC }\end{array}$ & $\begin{array}{c}\text { (2) } \\
\text { Full_i } \\
\text { LSDVC }\end{array}$ & $\begin{array}{c}\text { (3) } \\
\text { Final_- } \\
\text { LSDVC }\end{array}$ & $\begin{array}{c}\text { (4) } \\
\text { Full_sub } \\
\text { _GMM }\end{array}$ & $\begin{array}{c}\text { (5) } \\
\text { Full_sub_r } \\
\text { _GMM }\end{array}$ \\
\hline $\operatorname{Dep}_{\text {var }}(t-1)$ & $\begin{array}{c}0.5593^{\star \star \star} \\
(13.03)\end{array}$ & $\begin{array}{c}0.5513^{\star \star \star} \\
(12.86)\end{array}$ & $\begin{array}{c}0.5752^{\star \star \star} \\
(14.12)\end{array}$ & $\begin{array}{c}0.3378^{\star \star \star} \\
(4.33)\end{array}$ & $\begin{array}{c}0.3632^{\star \star \star} \\
(3.94)\end{array}$ \\
\hline Dep.var $(t-2)$ & & & & $\begin{array}{c}-0.0239 \\
(-0.64)\end{array}$ & $\begin{array}{c}-0.0543 \\
(-1.44)\end{array}$ \\
\hline$s b c_{-} b b$ & $\begin{array}{c}-2.3861^{\star} \\
(-1.93)\end{array}$ & $\begin{array}{c}-3.8625^{\star \star} \\
(-2.51)\end{array}$ & $\begin{array}{c}-2.3495^{*} \\
(-1.88)\end{array}$ & $\begin{array}{c}-2.3110^{\star \star} \\
(-2.27)\end{array}$ & $\begin{array}{c}-2.4204^{\star *} \\
(-2.06)\end{array}$ \\
\hline price_ull & $\begin{array}{c}-0.0182 \\
(-0.40)\end{array}$ & $\begin{array}{c}-0.0502 \\
(-1.06)\end{array}$ & $\begin{array}{c}-0.0207 \\
(-0.48)\end{array}$ & & $\begin{array}{l}0.0153 \\
(0.34)\end{array}$ \\
\hline i_price_ull_sh & & $\begin{array}{c}0.3112^{\star} \\
(1.77)\end{array}$ & & & \\
\hline$r d i \_b b$ & & & & & $\begin{array}{c}-0.0007 \\
(-0.00)\end{array}$ \\
\hline fms & $\begin{array}{c}-0.4770 \\
(-0.64)\end{array}$ & $\begin{array}{c}-0.3395 \\
(-0.44)\end{array}$ & $\begin{array}{c}-0.5590 \\
(-0.78)\end{array}$ & $\begin{array}{c}-1.4494^{\star \star \star} \\
(-2.66)\end{array}$ & $\begin{array}{c}-0.8625 \\
(-1.38)\end{array}$ \\
\hline$f m s^{2}$ & $\begin{array}{c}0.0048 \\
(0.09)\end{array}$ & $\begin{array}{c}0.0006 \\
(0.01)\end{array}$ & $\begin{array}{l}0.0136 \\
(0.26)\end{array}$ & $\begin{array}{c}0.0629^{\star *} \\
(2.10)\end{array}$ & $\begin{array}{c}0.0258 \\
(0.71)\end{array}$ \\
\hline cable & $\begin{array}{c}-6.3010^{\star \star} \\
(-2.06)\end{array}$ & $\begin{array}{c}-4.9659 \\
(-1.59)\end{array}$ & $\begin{array}{c}-6.5407^{\star \star} \\
(-2.46)\end{array}$ & $\begin{array}{c}1.9997 \\
(1.06)\end{array}$ & $\begin{array}{c}-2.4592 \\
(-0.60)\end{array}$ \\
\hline cable & $\begin{array}{c}8.6867^{\star \star \star} \\
(3.44)\end{array}$ & $\begin{array}{c}7.5363^{\star \star \star} \\
(2.95)\end{array}$ & $\begin{array}{c}9.3140^{\star \star \star} \\
(3.92)\end{array}$ & & $\begin{array}{c}4.9203^{\star} \\
(1.65)\end{array}$ \\
\hline legacy & $\begin{array}{c}-0.1629^{* \star \star} \\
(-2.83)\end{array}$ & $\begin{array}{c}-0.1523^{\star \star \star} \\
(-2.60)\end{array}$ & $\begin{array}{c}-0.1590^{\star * *} \\
(-2.93)\end{array}$ & $\begin{array}{l}-0.0694 \\
(-1.42)\end{array}$ & $\begin{array}{c}-0.0444 \\
(-0.83)\end{array}$ \\
\hline$b b \_l i n e s \_w$ & $\begin{array}{c}-14.1515^{\star *} \\
(-2.45)\end{array}$ & $\begin{array}{c}-15.0065^{\star *} \\
(-2.56)\end{array}$ & $\begin{array}{c}-11.5538^{\star *} \\
(-2.46)\end{array}$ & $\begin{array}{c}-10.3747^{\star} \\
(-1.94)\end{array}$ & $\begin{array}{c}-14.6078^{\star * *} \\
(-2.65)\end{array}$ \\
\hline $\ln (b b$ blines) & $\begin{array}{c}1.6169^{\star \star \star} \\
(2.96)\end{array}$ & $\begin{array}{c}1.1272^{\star} \\
(1.92)\end{array}$ & $\begin{array}{c}1.5364^{\star \star \star} \\
(4.55)\end{array}$ & $\begin{array}{c}0.4257 \\
(1.14)\end{array}$ & $\begin{array}{c}0.7765^{\star} \\
(1.67)\end{array}$ \\
\hline bus_lan & $\begin{array}{l}0.1819 \\
(0.09)\end{array}$ & $\begin{array}{c}0.3788 \\
(0.19)\end{array}$ & & & \\
\hline
\end{tabular}


Table 3 continued

\begin{tabular}{|c|c|c|c|c|c|}
\hline$g d p_{-} p c_{-} p p p$ & $\begin{array}{c}0.0002^{\star \star \star} \\
(2.82)\end{array}$ & $\begin{array}{c}0.0002^{* \star \star} \\
(3.11)\end{array}$ & $\begin{array}{c}0.0002^{* \star \star} \\
(3.34)\end{array}$ & $\begin{array}{c}0.0001^{\star \star \star} \\
(3.72)\end{array}$ & $\begin{array}{c}0.0001^{\star \star \star} \\
(3.72)\end{array}$ \\
\hline int_user & $\begin{array}{l}1.3606 \\
(0.43)\end{array}$ & $\begin{array}{l}1.7563 \\
(0.56)\end{array}$ & & $\begin{array}{c}4.1802^{\star \star} \\
(2.28)\end{array}$ & $\begin{array}{c}2.9389^{\star} \\
(1.92)\end{array}$ \\
\hline$n r i$ & $\begin{array}{l}0.4124 \\
(0.64)\end{array}$ & $\begin{array}{l}0.4214 \\
(0.65)\end{array}$ & & & \\
\hline$e d u$ & $\begin{array}{c}-0.0049 \\
(-1.05)\end{array}$ & $\begin{array}{c}-0.0049 \\
(-1.05)\end{array}$ & & $\begin{array}{c}0.0069^{\star \star} \\
(2.37)\end{array}$ & $\begin{array}{c}0.0109^{\star \star \star} \\
(3.25)\end{array}$ \\
\hline mdwell_perm & $\begin{array}{c}-0.0005 \\
(-0.48)\end{array}$ & $\begin{array}{c}-0.0007 \\
(-0.63)\end{array}$ & & & \\
\hline wage & $\begin{array}{c}-0.3308^{\star \star} \\
(-1.99)\end{array}$ & $\begin{array}{c}-0.3678^{\star \star} \\
(-2.21)\end{array}$ & $\begin{array}{c}-0.3741^{\star \star} \\
(-2.24)\end{array}$ & $\begin{array}{c}-0.2395^{\star} \\
(-1.67)\end{array}$ & $\begin{array}{c}-0.2098 \\
(-1.56)\end{array}$ \\
\hline urban_sh & $\begin{array}{c}0.9511^{\star \star \star} \\
(3.78)\end{array}$ & $\begin{array}{c}0.8840^{\star \star \star} \\
(3.40)\end{array}$ & $\begin{array}{c}0.9929^{\star \star \star} \\
(4.95)\end{array}$ & $\begin{array}{c}0.7146^{\star \star \star} \\
(3.48)\end{array}$ & $\begin{array}{c}0.9322^{\star \star \star} \\
(3.60)\end{array}$ \\
\hline Year dummies & NO & NO & NO & YES & YES \\
\hline Constant & & & & $\begin{array}{c}-48.3668^{\star \star \star} \\
(-3.04)\end{array}$ & $\begin{array}{c}-70.4924^{\star \star \star} \\
(-3.40)\end{array}$ \\
\hline$X^{2}$ & & & & $799 \cdot 5048$ & 729.7756 \\
\hline AR(1) test & & & & -1.6815 & -1.8673 \\
\hline $\begin{array}{l}A R(2) \text { test } \\
\text { Hansen test } \\
\text { (p-value) }\end{array}$ & & & & $\begin{array}{l}-1.4311 \\
(1.000)\end{array}$ & $\begin{array}{l}-1.2170 \\
(1.000)\end{array}$ \\
\hline Observations & 480 & 480 & 480 & 422 & 422 \\
\hline
\end{tabular}

$t$-statistics reported in parentheses are robust to heteroscedasticity in GMM estimates. All GMM estimates are based on the one-step procedure. In regr. (4) to (5) endogenous variables in first differences are instrumented with their own lagged levels dated $t-2$ to $t-6$. Note that using $\ln$ (fttx_sub) as the dependent variable involves six additional missing observations (compared to GMM regressions with the dependent variable In(fttx_total). All regressions include country-specific fixed effects. Whereas GMM estimations in regr. (4) to (5) also include period effects, we did not include year dummies for LSDVC estimations, because they were not jointly significant. For the Arellano-Bond tests for autocorrelation (AR(1) and $A R(2))$ and the Hansen test of over-identifying restrictions, test statistics and $p$-values, respectively, are reported. The LSDVC standard errors in regr. (1) to (3) are bootstrapped based on 100 iterations with bias correction initialized by the Arellano-Bond estimator for estimates up to order $\mathrm{O}(1 / \mathrm{T})$. Note that there are no standard post-estimation tests available in STATA for the user written "xtlsdvc" (Bruno, 2005b) command.

${ }^{\star} p<0.10,{ }^{\star \star} p<0.05,{ }^{\star \star \star} p<0.01$. 


\section{Summary and conclusions}

This work identifies the determinants of NGA investment using a recent and comprehensive panel data set for EU27 member states and multiple estimation methods, which enables robust inference in order to truly inform the ongoing policy debate at the national and EU level. We find strong evidence that previous broadband access regulations imposed on first-generation (legacy) infrastructure exert a significant and negative impact on aggregate NGA investment incentives. This effect can be found for the height of the relevant access charge (unbundling) as well as for regulatory-induced service-based competition, which is directly contingent on access regulations. Whereas there is some ambiguity as regards the theoretical effects at the firm level, there is a clear evidence with respect to the overall effect in terms of total NGA investment: Accordingly, we find that an increase in the intensity of service-based competition by 1 percentage point, decreases total NGA investment by at least $\sim 1.58 \%$ and up to $\sim 5.30 \%$. As regards the impact of the unbundling charge, our results show that a higher access charge increases total NGA investment and that this effect gets more pronounced the more effective the unbundling regime is, i.e. with a higher unbundling market share. In view of the above, our results provide no empirical support for the ladder of investment hypothesis. These findings correspond well with the previous empirical and theoretical literature.

As regards the impact of infrastructure-based competition from mobile and cable networks our results are inconclusive and do not find a non-linear impact as found in the related empirical literature. The latter might result from the fact that polynomical terms show good in-sample fit but lower out of-sample validity. However, we find some evidence that the incumbent's legacy infrastructure is subject to a replacement effect which is not the case for the first-generation infrastructure of cable operators. These differences in the results can be 
plausibly related to differences in network-upgrading costs and with respect to the wholesale revenue effect, which only impacts on the profitability of the regulated incumbent operator.

With regard to the impact of demand- and cost-side factors, our results show that the size of the conventional broadband market has a very strong impact on NGA investment incentives, whereas a highly saturated broadband market involves strong switching costs that hinder migration to NGA services. Regarding the cost side, we find that the level of urbanization appears to be a highly important determinant of NGA investment. Moreover, our results indicate that NGA deployment is subject to adjustment cost.

Whereas most of the explanatory variables represent market-driven outcomes or country-specific conditions, regulatory variables represent discretionary policy decisions of NRAs. As our results indicate, strict access regulations exert not only a significantly negative but also a substantial impact on NGA investment decisions, which should be taken into careful consideration in future regulatory decision making. According to our results, and in line with the vast majority of the previous and related literature, deregulatory approaches imposed on first- and second-generation infrastructure lead to an increase in NGA investment and, most likely, also to welfare gains, not least because of the currently rather low NGA deployment levels in most EU member states. In this view, the existing regulatory framework in Europe is at odds with the ambitious NGA deployment and adoption goals of the "Digital Agenda" (European Commission, 2010b).

Regarding the welfare implications, however, we only provide some tentative evidence, and further research is required here. The same applies as regards empirical research based on firm-level data that also allows tests of differential investment incentives and strategic effects as predicted by the theoretical literature. 


\section{Appendix}

See Tables A.1 to A.2

Table A.1: Variable description and sources

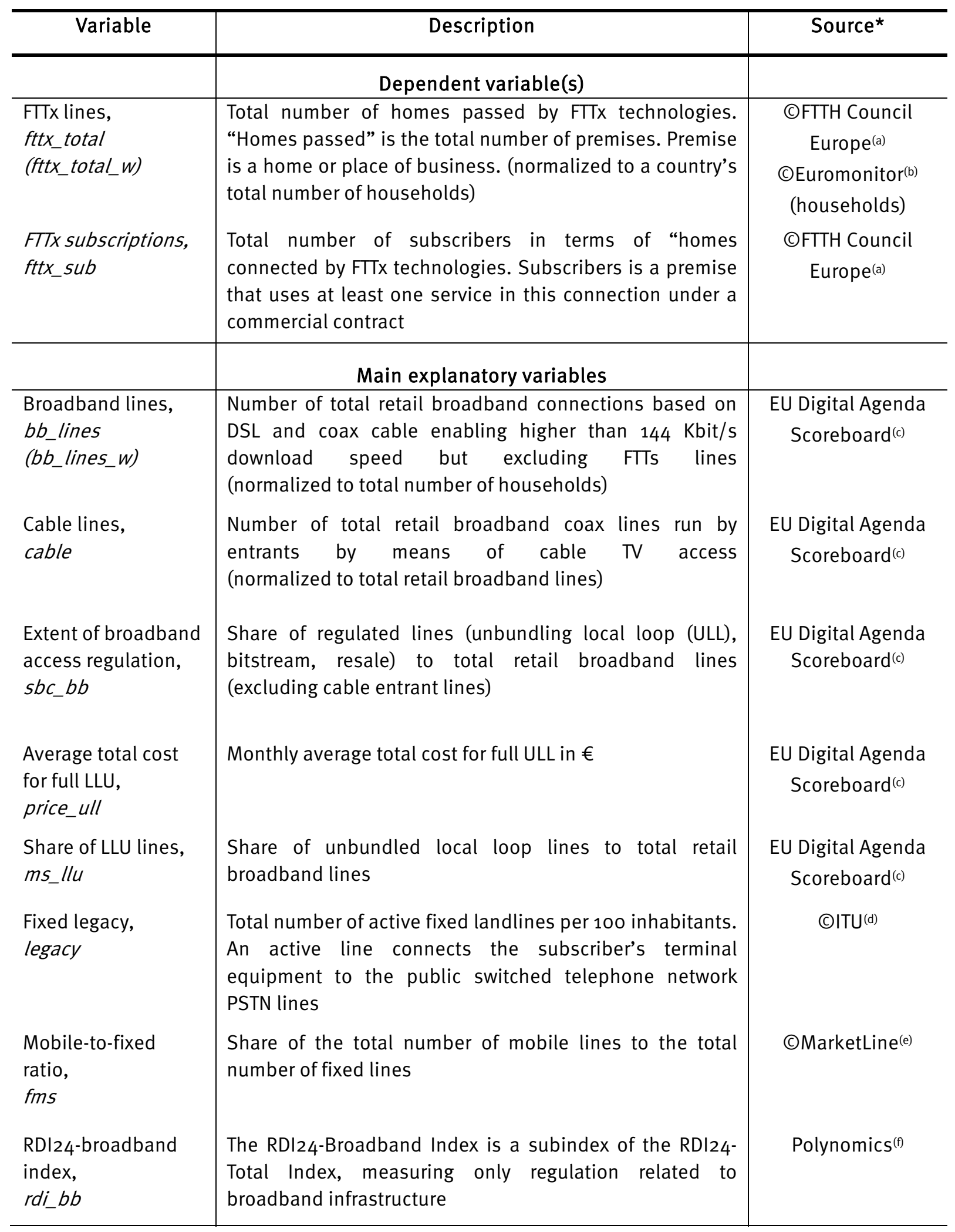




\begin{tabular}{|c|c|c|}
\hline Variable & Description & Source* \\
\hline & Demand control variables & \\
\hline $\begin{array}{l}\text { Businesses with } \\
\text { LAN, } \\
\text { bus_use_lan }\end{array}$ & $\begin{array}{l}\text { Share of a country's businesses that have a local area } \\
\text { network (LAN) }\end{array}$ & (C)Euromonitor (b) \\
\hline $\begin{array}{l}\text { Internet users, } \\
\text { int_user }\end{array}$ & Share of a country's population that is using the Internet & (C) Euromonitor ${ }^{(b)}$ \\
\hline $\begin{array}{l}\text { Education, } \\
\text { edu }\end{array}$ & $\begin{array}{l}\text { Total number of graduates in all programmes in 'ooo } \\
\text { persons }\end{array}$ & (c) Euromonitor ${ }^{(b)}$ \\
\hline \multirow[t]{2}{*}{$\begin{array}{l}\text { GDP per capita, } \\
g d p_{-} p c_{-} p p p\end{array}$} & GDP per capita and PPP adjusted in current US\$ & World Bank(g) \\
\hline & Cost control variables & \\
\hline $\begin{array}{l}\text { Building permits, } \\
\text { mdwell_perm }\end{array}$ & $\begin{array}{l}\text { Building permits for two and more dwellings as annual } \\
\text { index normalized to } 100 \text { in } 2010\end{array}$ & Eurostat $(\mathrm{h})$ \\
\hline $\begin{array}{l}\text { Hourly wage, } \\
\text { wage }\end{array}$ & $\begin{array}{l}\text { The manufacturing wage per hour in } € \text { and current prices } \\
\text { with fixed } 2012 \text { exchange rates }\end{array}$ & (C) Euromonitor(b) \\
\hline $\begin{array}{l}\text { Labour cost, } \\
\text { labcost_con }\end{array}$ & $\begin{array}{l}\text { Annual labour cost index for the Construction branch by } \\
\text { NACE Rev. } 2 \text { normalized to } 100 \text { in } 2008 \text {. The index } \\
\text { measures the development of the total cost, on an hourly } \\
\text { basis, for employing the labor force, including wages and } \\
\text { salaries, social security contributions, taxes, excluding } \\
\text { subsidies }\end{array}$ & Eurostat ${ }^{(h)}$ \\
\hline $\begin{array}{l}\text { Urban population, } \\
\text { urban_share }\end{array}$ & $\begin{array}{l}\text { Population of a country that lives in an urban environment } \\
\text { as percentage of the total population }\end{array}$ & (C)MarketLine ${ }^{(\mathrm{e})}$ \\
\hline
\end{tabular}

* Note that some sources are commercially available only (@), while others are publicly available. (a) FTTH Council Europe is a non-profit industry organization, the aim of which is to enforce the deployment of fibre-optic technology in Europe. Data are collected by IDATE (www.idate.org) through desk research, direct contact with FTTx players, information exchange with FTTH Council Europe members and from IDATE partners. FTTH Council Europe provides annual data for the years from 2005 to 2013. Annual data for the independent variables (sources (b) to (h)) are available for the years from 2004 to 2012. (b) The Euromonitor International database is available at: http://www.euromonitor.com/. (c) The EU "Digital Agenda Scoreboard" is available at: http://ec.europa.eu/information_society/policy/ecomm/library/communications_reports/index_en.ht. There are missing values for Bulgaria and Romania for the years from 2004 to 2005. (d) The ITU World Telecommunication/ICT Indicators Database is available at: http://www.itu.int/ITU-D/ict/statistics/. (e) Data are available at: http://advantage.marketline.com/PageForbidden?returnUrl=\%2F. (f) The Polynomics Regulation Index is available at: http://www.polynomics.ch/rdi.php. (g) The World Bank's “World Development Indicators" are available at: http://data.worldbank.org. (h) Data are available at: http://epp.eurostat.ec.europa.eu/portal/page/portal/information_society/data/database. 
Table A.2: Summary statistics

\begin{tabular}{llllll}
\hline Variable & Obs & Mean & Std. Dev. & Min & Max \\
\hline ftt__total & 270 & 2072843 & 4706856 & 1 & $3.75 \mathrm{e}+07$ \\
In(fttx_total) & 270 & 10.63032 & 5.608084 & 0 & 17.43946 \\
ftt__total_w & 270 & .1315215 & .1648317 & $1.21 \mathrm{e}-08$ & .7351943 \\
In(fttx_total_w) & 247 & -5.789674 & 5.302496 & -18.22869 & -.4238326 \\
ftt__sub & 270 & 316400.6 & 668623.5 & 1 & 5144100 \\
In(fttx_sub) & 270 & 9.32781 & 4.685692 & 0 & 15.45336 \\
bb_lines & 267 & 3723236 & 5769546 & 13738 & $2.80 \mathrm{e}+07$ \\
bb_lines_w & 267 & .1904645 & .0973223 & .0023487 & .4044925 \\
cable & 254 & .2157732 & .1649066 & 0 & 1 \\
sbc_bb & 239 & .194315 & .197063 & 0 & .9705678 \\
price_ull & 239 & 11.72037 & 4.383839 & 5.34 & 42 \\
ms_ull & 239 & .1014437 & .1406279 & 0 & .6772212 \\
i_price_ullsh & 254 & 1.112611 & 1.496397 & 0 & 7.07019 \\
legacy & 243 & 40.88424 & 12.98943 & 15.98503 & 66.38055 \\
fms & 269 & 3.375306 & 1.669958 & 1.2819 & 10.9396 \\
rdi_bb & 243 & .6995885 & .322663 & 0 & 1 \\
bus_use_lan & 270 & .7118741 & .1566787 & .231 & .996 \\
int_user & 270 & .6368203 & .1846024 & .1500006 & .951 \\
edu & 243 & 68.96461 & 13.13021 & 26 & 86.6 \\
gdp_pc_ppp & 243 & 29783.69 & 13548.51 & 8730.803 & 89055.8 \\
mdwell_perm & 243 & 161.4842 & 134.003 & 12.54 & 913.39 \\
wage & 269 & 11.06208 & 7.875111 & .8 & 38.7 \\
labcost_con & 243 & 95.7 & 14.85244 & 39.8 & 134.7 \\
urban_sh & 270 & 72.43043 & 11.89043 & 49.4118 & 97.4945 \\
\hline & & & & &
\end{tabular}




\section{Acknowledgements}

The author is grateful to Deutsche Telekom AG for co-funding this research project and for helpful comments and suggestions provided by Prof. Carlo Cambini and Prof. Klaus Gugler and the participants at the 25th European Regional ITS Conference in Brussels and at the HFMWorkshop “Wettbewerb und Regulierung im Internet” in Hamburg. 


\section{References}

Aghion, P., Bloom, N., Blundell, R., Griffith, R. \& P. Howitt (2005), Competition and Innovation: An Inverted-U Relationship, Quarterly Journal of Economics 120, 701-728.

Arellano, M. \& S. Bond (1991), Some Tests of Specification for Panel Data: Monte Carlo Evidence and an Application to Employment Equations, Review of Economic Studies 58 , 277-297.

Arellano, M. \& O. Bover (1995), Another Look at the Instrumental-Variable Estimation of ErrorComponents Models, Journal of Econometrics 68, 29-51.

Arrow, K.J. (1962), Economic Welfare and the Allocation of Resources to Invention, in: Nelson, R.R. (Ed.), The Rate and Direction of Economic Activity, Princeton, New York, 609-626.

Bacache, M., Bourreau, M. \& G. Gaudin (2014), Dynamic Entry and Investment in New Infrastructures: Empirical evidence from the Telecoms Industry, Review of Industrial Organization 44, 179-209.

Blundell, R. \& S. Bond (1998), Initial Conditions and Moment Restrictions in Dynamic Panel Data Models, Journal of Econometrics 87, 115-143.

Bond, S. (2002), Dynamic Panel Data Models: A Guide to Micro Data Methods and Practice, Working Paper, Centre for Microdata Methods and Practice, CWPog/o2.

Bourreau, M., Cambini, C. \& P. Dogan (2012), Access Pricing, Competition, and Incentives to Migrate From “Old” to “New” Technology, International Journal of Industrial Organization 30, 713-723.

Bourreau, M., Cambini, C. \& P. Dogan (2014), Access Regulation and the Transition from Copper to Fibre in Telecoms, Journal of Regulatory Economics 45, 233-258.

Bresnahan, T. \& M. Trajtenberg (1995), General Purpose Technologies: “Engines of Growth”? Journal of Econometrics 65, 83-108.

Briglauer, W. (2014), The Impact of Regulation and Competition on the Adoption of Fibre-Based Broadband Services: Recent Evidence from the European Member States, Journal of Regulatory Economics 46, 51-79.

Briglauer, W. \& S. Frübing (2014), Sektorspezifische Regulierung und Investitionen in neue glasfaserbasierte Kommunikationsinfrastrukturen: Eine ökonomische Bestandsaufnahme, Netzwirtschaften\&Recht5/14, 198-204.

Briglauer, W., Ecker, G. \& K. Gugler (2013), The Impact of Infrastructure- and Service-based Competition on the Deployment of Next Generation Access Networks: Recent Evidence from the European Member States, Information Economics and Policy25, 142-153. 
Briglauer, W. \& K. Gugler (2013), The Deployment and Penetration of High-Speed Fibre Networks and Services: Why are European Member States Lagging Behind? Telecommunications Policy 37, 819-835.

Brito, D., Pereira, P. \& J. Vareda (2010), Can Two-Part Tariffs Promote Efficient Investment on Next Generation Networks? International Journal of Industrial Organization 28, 323-33.

Bruno, G. (2005a), Approximating the Bias of the LSDV Estimator for Dynamic Unbalanced Panel Data Models, Economics Letters 87, 361-366.

Bruno, G. (2005b), Estimation and Inference in Dynamic Unbalanced Panel-Data Models with a Small Number of Individuals, The Stata Journa/5, 473-500.

Cambini, C. \& Y. Jiang (2009), Broadband Investment and Regulation: A Literature Review, Telecommunications Policy33, 559-574.

Cambini, C. \& V. Silvestri (2012), Technology Investment and Alternative Regulatory Regimes with Demand Uncertainty, Information Economics and Policy 24, 212-230.

Cave, M. (2006), Encouraging Infrastructure Investment via the Ladder of Investment, Telecommunications Policy30, 223-237.

Cave, M. \& I. Vogelsang (2003), How Access Pricing and Entry Interact, Telecommunications Policy 27, 717-727.

Crandall, R.W., Jeffrey A., \& Ingraham, A. (2013). The long-run effects of copper-loop unbundling and the implications for fiber. Telecommunications Policy37, 262-281.

Czernich, N., Falck, O., Kretschmer, T. \& L. Wößmann (2011), Broadband Infrastructure and Economic Growth, The Economic Journal 121, 505-532.

Etro, F. (2009), The Economic Impact of Cloud Computing on Business Creation, Employment and Output in Europe: An Application of the Endogenous Market Structures Approach to a GPT Innovation, Review of Business and Economics 59, 179-208.

European Commission (2010a), Commission Recommendation of 20 September 2010 on Regulated Access to Next Generation Access Networks (NGA), 2010/572/EU, Brussels.

European Commission (2010b), A Digital Agenda for Europe, COM(2010) 245, Brussels.

Foros, $\varnothing$. (2004), Strategic investments with spillovers, vertical integration and foreclosure in the broadband access market, International Journal of Industrial Organization 22, 1-24.

FTTH Council Europe (2012a), The cost of meeting Europe's network needs: The cost of putting in place an infrastructure now, that will meet the Digital Agenda targets for 2020, 2030, 2040 and beyond, final report. Retrieved from http://www.ftthcouncil.eu/documents/Reports/Cost_Model_Report_Full_Version.pdf. 
FTTH Council Europe (2012b), FTTH Business Guide, 3rd edition (Revision date: 07/02/2012), Retrieved from http://www.fthcouncil.eu/home/form-business-guide\#.

Grajek, M. \& L.H. Röller (2011), Regulation and Investment in Network Industries: Evidence from European Telecoms, Journal of Law and Economics 55, 189-216.

Inderst, R. \& M. Peitz (2012), Market Asymmetries and Investments in Next Generation Access Networks, Review of Network Economics 11, 1-25.

Kiiski, S. \& M. Pohjola (2002), Cross-Country Diffusion of the Internet, Information Economics and Policy14, 297-310.

Klumpp, T. \& X. Su (2010), Open Access and Dynamic Efficiency, American Economic Journal: Microeconomics 2, 64-96.

Koutroumpis, P. (2009), The Economic Impact of Broadband on Growth: A Simultaneous Approach, Telecommunications Policy 33, 471-485.

Kotakorpi, K. (2006), Access price regulation, investment and entry in telecommunications, International Journal of Industrial Organization 24, 1013-1020.

Muselaers, N. \& R. Stil (2010), Regulation, Risk and Investment Incentives, report by OPTA Expertise Centre. Retrieved from http://www.opta.nl/en/download/publicatie/?id=3201.

Nickell, S. (1981), Biases in Dynamic Models with Fixed Effects, Econometrica 49, 1417-1426.

Nitsche, R. \& L. Wiethaus (2011), Access Regulation and Investment in Next Generation Networks - A Ranking of Regulatory Regimes, International Journal of Industrial Organization 29, 263-272.

OECD (2009), Network Developments in Support of Innovation and User Needs, DSTI/ICCP/CISP(2009)2/FINAL, Paris.

Pindyck, R.S. (2007), Mandatory Unbundling and Irreversible Investment in Telecom Networks, Review of Network Economics 6, 274-298.

Roodman, D. (2006), How to do xtabond2: An Introduction to "Difference" and "System" GMM in Stata, Working paper No. 103, Center for Global Development.

Roodman, D. (2009), Practitioners'Corner: A Note on the Theme of Too Many Instruments, Oxford Bulletin of Economics and Statistics 71, 135-157.

Röller, L.H. \& L. Waverman (2001), Telecommunications Infrastructure and Economic Development: A Simultaneous Approach, American Economic Review 91, 909-923. 
Samanta, S.K., Martin, R., Guild, K. \& Pan, H. (2012), The Diffusion of High Speed Broadband: A Cross Country Analysis, working paper. Retrieved from http://papers.ssrn.com/sol3/papers.cfm?abstract_id=1997113.

Schmutzler, A. \& Sacco, D. (2011), Is there a U-shaped relation between competition and investment? International Journal of Industrial Organization 29, 65-73.

Valletti, T. (2003), The Theory of Access Pricing and Its Linkage with Investment Incentives, Telecommunications Policy 27, 659-675.

Vareda, J. (2010), Access regulation and the incumbent investment in quality-upgrades and in cost-reduction, Telecommunications Policy34, 697-710.

Vogelsang, I. (2014), Will the U.S. and EU Telecommunications Policies Converge? A Survey, CESifo Working Paper No. 4843, Munich.

Wallsten, S. \& S. Hausladen (2009), Net Neutrality, Unbundling, and Their Effects on International Investment in Next-Generation Networks, Review of Network Economics 8 , Article 6.

Wooldridge, J. (2002), Econometric Analysis of Cross Section and Panel Data, MIT Press, Cambridge. 